\title{
The effect of information shocks on dividend payout and dividend value relevance
}

DOI:

10.1016/j.irfa.2018.10.009

\section{Document Version}

Accepted author manuscript

Link to publication record in Manchester Research Explorer

\section{Citation for published version (APA):}

Harakeh, M., Lee, E., \& Walker, M. (2018). The effect of information shocks on dividend payout and dividend value relevance. International Review of Financial Analysis. https://doi.org/10.1016/j.irfa.2018.10.009

\section{Published in:}

International Review of Financial Analysis

\section{Citing this paper}

Please note that where the full-text provided on Manchester Research Explorer is the Author Accepted Manuscript or Proof version this may differ from the final Published version. If citing, it is advised that you check and use the publisher's definitive version.

\section{General rights}

Copyright and moral rights for the publications made accessible in the Research Explorer are retained by the authors and/or other copyright owners and it is a condition of accessing publications that users recognise and abide by the legal requirements associated with these rights.

\section{Takedown policy}

If you believe that this document breaches copyright please refer to the University of Manchester's Takedown Procedures [http://man.ac.uk/04Y6Bo] or contact uml.scholarlycommunications@manchester.ac.uk providing relevant details, so we can investigate your claim.

\section{OPEN ACCESS}




\title{
'The differential impact of IFRS adoption on aspects of seasoned equity offerings in the UK and France'
}

\author{
Mostafa Harakeh*, Edward Lee ${ }^{* *}$, \& Martin Walker ${ }^{* * *}$
}

"Finance and Accounting Department, Adnan Kassar School of Business, Lebanese American University. Email: mostafa.harakeh@lau.edu.lb. Phone number: +9611786456, Ext. 1802.

** Accounting and Finance Group, Alliance Manchester Business School, The University of Manchester, Manchester, UK. Email: edward.lee@ manchester.ac.uk. Phone number: +44 (0) 161 2754564.

**** Accounting and Finance Group, Alliance Manchester Business School, The University of Manchester, Manchester, UK. Email: martin.walker@manchester.ac.uk. Phone number: +44 (0) 1612754008 .

Corresponding author: Mostafa Harakeh, Finance and Accounting Department, Adnan Kassar School of Business, Lebanese American University, Chouran Beirut: 1102 2801. Email: mostafa.harakeh@lau.edu.lb. 


\title{
The differential impact of IFRS adoption on aspects of seasoned equity offerings in the UK and France
}

\begin{abstract}
We examine the potential for IFRS to influence the market for SEOs in the UK and France. The divergence between the UK domestic accounting standards and IFRS is minor (low-divergence firms) whereas domestic accounting standards in France differ materially from IFRS (high-divergence firms); however, both countries have similar legal enforcement and institutional settings that might confound the effect of IFRS adoption. We argue that IFRS adoption serves to mitigate information asymmetry and improve accounting quality. Accordingly, we find that, following IFRS adoption, earnings management activities decrease among high-divergence firms prior to issuing SEOs. As a result of the lower levels of earnings management and information asymmetry, we predict and find that the market reaction to issuing SEOs improves significantly for high-divergence firms following IFRS. Given that equity financing becomes less costly, we find that the propensity to issue new SEOs increases among high-divergence firms after IFRS adoption. We find no similar changes among low-divergence firms. The results persist after running a matched-sample analysis and controlling for potential self-selection bias.
\end{abstract}

Keywords: IFRS, Information Asymmetry, Earnings Management, Seasoned Equity Offerings, Equity Financing. 


\section{Introduction}

Since the implementation of International Financial Reporting Standards (IFRS) in 2005 in the European Union, a large number of studies have examined the consequences of the mandatory adoption of IFRS. This paper adds to this long standing literature and examines the effect of IFRS adoption on various aspects of seasoned equity offerings (SEOs). Specifically, we evaluate the change in the level of earnings management prior to issuing SEOs, the change in the market reaction to SEO announcements and the change in the propensity to issue SEOs following the IFRS mandate.

We examine these issues using a difference-in-differences research design, after we control for potential factors that might confound with IFRS adoption. Despite that IFRS were mandated in the UK and France simultaneously, we expect IFRS adoption to have a marginal effect on the financial reporting environment in the UK as opposed to a material effect in France. This differential impact of IFRS on the financial reporting environment in the UK and France is mainly determined by the divergence between domestic accounting standards and IFRS in both countries. Firms listed in countries with domestic accounting standards similar to IFRS are not expected to witness a shock to their corporate financial information environment, unlike firms listed in countries with domestic accounting standards that differ materially from IFRS. Therefore, to identify the effect of IFRS adoption, we select two countries with different domestic accounting standards relative to IFRS, yet with similar institutional settings, legal enforcement, and investor's protection. Bae, Tan, \& Welker (2008) construct an index that measures to what extent domestic accounting standards differ from international accounting standards (IAS) in 49 countries. Their index shows that domestic accounting standards in France have 12 key accounting items that do not conform to IAS. On the other hand, the index shows 
that domestic accounting standards in the UK have only 1 key accounting item that does not conform to IAS. ${ }^{1}$ As such, we label French firms as high-divergence firms and UK firms as lowdivergence firms. Based on this setting, we formulate the following three hypotheses.

First, we hypothesize that IFRS adoption will moderate earnings management prior to issuing SEOs among high-divergence firms. Warfield, Wild, \& Wild (1995) find that the level of earnings management is higher when information asymmetry is higher. In an SEO setting, Teoh et al. (1998) and Shivakumar (2000) find that managers manipulate earnings prior to SEO announcements. To the extent IFRS mitigate information asymmetry (Daske, Hail, Leuz, \& Verdi, 2008; Muller, Riedl, \& Sellhorn, 2011) and improve accounting quality (Barth, Landsman, \& Lang, 2008), we expect mandatory adoption of IFRS to reduce the level of earnings management prior to issuing SEOs.

Second, we hypothesize that the market reaction to SEO announcements will become more favorable among high-divergence firms following IFRS adoption. Myers \& Majluf (1984) theorize that the main reason behind the high cost associated with equity financing is the existence of asymmetric information, relating to assets in place, between managers and investors. Therefore, we argue that if IFRS serve to mitigate information asymmetry relating to assets in place, then the market should attach a lower discount rate for SEOs after mandatory IFRS adoption.

Third, we hypothesize that the propensity to issue SEOs will increase after IFRS adoption among high-divergence firms. Eckbo, Masulis, \& Norli (2007) document that issuing SEOs is a rare phenomenon among public firms because investors underprice the offered shares due to the existence of asymmetric information and the adverse selection problem. If the market reaction to

\footnotetext{
${ }^{1}$ In a similar study, Ding, Hope, Jeanjean, \& Stolowy (2007) construct an index that includes 111 international accounting items and document that 21 items are missing from the French domestic accounting standards whereas the UK domestic accounting standards include all the international accounting items.
} 
SEO announcements becomes more favorable under IFRS, then managers are expected to issue SEOs more frequently.

The empirical findings are consistent with our hypotheses. First, we find that the level of earnings management, prior to issuing SEOs, decreases after IFRS adoption among highdivergence firms compared to low-divergence firms. This finding holds after controlling for real earnings management (Cohen \& Zarowin, 2010) and idiosyncratic economic shocks (Owens, $\mathrm{Wu}, \&$ Zimmerman, 2017). Next, we find that the market reaction to SEO announcements improves after IFRS adoption among high-divergence firms compared to their low-divergence counterparts. This finding holds after controlling for potential self-selection bias (Heckman, 1979). Finally, we find that the propensity to issue SEOs increases after IFRS adoption among French firms compared to UK firms. The consistency of observing IFRS impact on the highdivergence group, as opposed to the low-divergence group, reduces the likelihood that our findings are attributed to other unidentified confounding effects.

As a robustness check, we run a matched-sample analysis in order to compare firms that fall on the common support area of the distribution. We use Coarsened Exact Matching (Iacus, King, \& Porro, 2012), where we match each high-divergence observation to a low-divergence observation based on total assets, industry, and IFRS time period. The results hold after running the matched-sample analyses and our conclusions remain unchanged.

Our findings reconcile with Hong et al. (2014) who find that the market reaction to IPOs has improved globally following IFRS adoption. Our study contributes further to Hong et al. (2014) by showing that the effect of IFRS adoption on equity financing is not only transitory around the first equity offering (IPOs), but also permanent around later equity offerings (SEOs). Moreover, our sample selection focuses on the high comparability between the high-divergence and low- 
divergence groups, based on economic and institutional factors which cannot be entirely controlled for in international studies.

In a similar study to ours, Fauver, Loureiro, \& Taboada (2017) examine the impact of financial directives, which were also enacted in 2005, on information quality and stock performance around SEOs using a sample of $18 \mathrm{EU}$ countries. They find a reduction in the level of accrual-based earnings management prior to issuing SEOs, a better long-run stock performance, and an improvement in the market reaction to SEO announcements. Nevertheless, our study differs from Fauver et al. (2017) in three aspects. First, we show that the changes in the levels of earnings management and the market reaction around SEOs are not homogenous among EU countries. Unlike Fauver et al. (2017), we select two capital markets with similar institutional factors but with accounting standards that diverge differently from IFRS. We argue that our restricted sample provides a more controlled research setting compared to international samples; such a restricted sample isolates potential confounding effects and enables a better identification of the differential impact of IFRS adoption (Leuz, 2003), which is mainly a function of the divergence between domestic accounting standards and IFRS. Second, despite the fact that it is very difficult to disentangle the effects of IFRS and financial directives due to their contemporaneous enactment, we believe that the similarity between institutional factors in the UK and France, including the fact that the financial directives were enacted in July 2005 in both countries, partially isolates the confounding effect of these financial directives on IFRS adoption. Third, prior studies show that the mandatory adoption of IFRS is the dominant contributor to improving the financial information environment (Barth et al., 2008) and hence mitigating information asymmetry around equity issuance (Hong et al., 2014). In the light of evidence that the aforementioned benefits of the IFRS mandate were also found in countries that did not 
witness the enactment of financial directives (i.e., non-EU countries) (Christensen, Hail, \& Leuz, 2013), we argue that our results are mainly attributed to IFRS adoption and not to other contemporaneous events. Accordingly, our research setting and sample selection adds to the long standing literature on the effects of IFRS adoption (see the survey of De George, Li, \& Shivakumar, 2016) by identifying the differential impact of IFRS on one of the most fundamental issues in capital markets, i.e., equity financing.

Finally, our results reconcile the findings of leading studies in the corporate finance literature, such as Lee \& Masulis (2009) who show that better accounting information leads to lower floatation costs associated with SEOs, by showing that the adoption of accounting standards associated with higher quality carries positive implications on aspects of equity financing. As such, the current study tackles a fundamental issue in equity markets that deserves a thorough examination (see the SEO survey of Eckbo et al., 2007).

The remainder of the paper is structured as follows: section 2 provides the literature review and hypotheses development; section 3 discusses the research design; section 4 describes the data sample; section 5 discusses the main results along with the robustness checks; and section 6 concludes.

\section{Motivation and Literature Review}

\subsection{Information asymmetry in the SEO setting}

Myers \& Majluf (1984) theorize that equity financing is costly under information asymmetry relating to assets in place. Uninformed investors discount the value of the offered shares because of high ex-ante uncertainty, which increases under asymmetric information (Akerlof, 1970). Consistent with the information asymmetry theory, Rock (1986) states that the issuing firm must offer a higher price discount when the level of uncertainty relating to the fundamental value of 
the offered shares is higher. Corwin (2003), among others, provides evidence suggesting that the market reaction to SEOs issued by firms with high levels of information asymmetry and uncertainty is more negative. Therefore, theoretical models and empirical findings agree on the strong association between information asymmetry and equity under-pricing.

\subsection{Earnings management around SEOs}

The tendencies of poor stock returns and poor earnings performance, subsequent to SEOs, have induced researchers to suspect that earnings are being managed prior to issuing new equity (Rangan, 1998; Shivakumar, 2000; Teoh et al., 1998). Rangan (1998) and Teoh et al. (1998) find that firms that issue SEOs have high abnormal accruals prior to the issue date and, accordingly, experience a long-term stock underperformance and a predictable decline in earnings. Shivakumar (2000) finds similar results to Rangan (1998) and Teoh et al. (1998), but he reaches

a different conclusion from theirs. In contrast to Rangan (1998) and Teoh et al. (1998), who conclude that managers manipulate their earnings prior to issuing SEOs in order to mislead investors, Shivakumar (2000) theorizes that investors react efficiently to manipulated earnings by undoing the manipulation effect through under-pricing the issued SEOs. Despite the difference in the conclusions of the aforementioned authors, they all find significant evidence of accruals earnings management activities prior to SEOs.

\subsection{The market reaction and the propensity to issue SEOs}

The finance literature documents strong evidence showing a negative reaction to issuing new SEOs (Denis, 1994; Eckbo \& Masulis, 1995; Jung, Kim, \& Stulz, 1996; Masulis \& Korwar, 1986; Mikkelson \& Partch, 1986). These studies attribute this common finding to the existence of asymmetric information, relating to the firm value, between managers and investors. Prior studies show that firms with better financial information environments can raise equity at a lower 
cost (Eckbo et al., 2007; Lang \& Lundholm, 2000; Lee \& Masulis, 2009; McLean, Pontiff, \& Watanabe, 2009). This is confirmed by Hovakimian \& Hutton (2010) who find that firms that enjoy a better market reaction to the first SEO and a better ex-post stock performance, have a higher probability of issuing another SEO.

\subsection{IFRS and the corporate information environment}

There is an ongoing debate in the literature over the impact of IFRS adoption on the corporate information environment, and in particular on earnings management activities. For example, Callao \& Jarne (2010) find that earnings management has intensified following IFRS adoption in the European Union while Houqe, van Zijl, Dunstan, \& Karim (2012) find that mandatory IFRS adoption deterred earnings management activities especially in countries with strong investor protection. A similar controversy arises in single-country studies. For example, Christensen, Lee, Walker, \& Zeng (2015) show that only firms that adopted IFRS voluntarily (and not mandatorily) witnessed a reduction in their level of earnings management in Germany, which suggests that firm incentives are the main determinant of accounting practices and not accounting standards per se. On the other hand, Ernstberger, Stich, \& Vogler (2012) find a reduction in the level of earnings management activities in Germany for mandatory adopters of IFRS. Moreover, other studies provide evidence suggesting a favorable impact of mandatory IFRS adoption on the corporate information environment in general and on earnings quality in specific. Such studies find that mandatory IFRS adoption is associated with an increase in the number of issues of management forecasts among firms with higher earnings quality especially in code-law countries ( $\mathrm{Li} \&$ Yang, 2016), an increase in the information content of earnings (Landsman, Maydew, \& Thornock, 2012), and an improvement in forecast accuracy and other measures of information environment quality (Horton, Serafeim, \& Serafeim, 2013). 
In the context of equity financing, Hong et al. (2014) study the effect of mandatory IFRS adoption on the market reaction to IPOs using an international sample. Their findings suggest that mandatory IFRS adoption reduces information asymmetry and, consequently, helps firms raise capital at a lower cost. ${ }^{2}$ In general, if IFRS adoption increases the level of disclosure and improves accounting quality (Armstrong, Barth, Jagolinzer, \& Riedl, 2010; Barth et al., 2008; Brüggemann, Hitz, \& Sellhorn, 2013; Horton et al., 2013), which in turn mitigates information asymmetry and facilitates monitoring, then one would expect a reduction in the level of earnings management prior to SEOs. Of course, it is also possible that the reduction in earnings management activities do not apply to all public firms and are specific to firms that intend to pursue equity financing. Since financial reporting and disclosure are widely recognized to be of lower quality in code-law countries (La Porta et al., 2000; Lee \& Masulis, 2009; SingletonGreen, 2015), IFRS adoption in such countries should also induce more pronounced improvement of market reactions to equity financing. If the market reaction to SEOs improves after IFRS adoption, which reduces the cost of equity financing, then we would expect an increase in the propensity to issue new equity following IFRS adoption.

\subsection{Hypotheses development}

The most common explanation for the typical negative stock price reaction to the announcement of SEOs is the adverse selection effect proposed by Myers \& Majluf (1984). Under this argument, due to high information asymmetry, investors perceive the managerial decision to issue SEOs as a signal that the issued shares are overpriced and thus react by lowering the offered price. According to Shivakumar (2000), investors react negatively to SEOs since they assume that managers overstate earnings in order to increase stock prices before issuing new

\footnotetext{
${ }^{2}$ In Europe, André $(2017$, p. 7) mentions a number of studies that find that companies adopt IFRS to optimize their financing activities and prior to issuing new equity.
} 
stocks. For that reason, investors reach an equilibrium by undoing the manipulation effect by lowering stock prices. This problem intensifies under higher levels of information asymmetry and aggressive earnings management. The adoption of IFRS that is found to improve accounting quality and enhance disclosure could improve firms' information environment and therefore mitigate the adverse selection problem around SEO announcements. This extends to managers who do not manipulate earnings prior to issuing SEOs but are reluctant to issue equity because of the anticipated negative market reaction (Myers \& Majluf, 1984, p.196). Such managers are more likely to issue SEOs following IFRS adoption since investors are expected to react less negatively, due to their increased confidence in accounting numbers reported under IFRS. In other words, IFRS facilitate financial communication between managers and investors, allowing managers to better assure investors about their funds.

As mentioned in the introduction, the impact of IFRS adoption on the corporate financial information environment in an adopting country depends heavily on the divergence between the country's domestic accounting standards and IFRS, holding the institutional factors constant. The distinction between low-divergence and high-divergence firms partially stems from the legal system of the country. In particular, accounting standards differ substantially between commonlaw and code-law legal systems (Soderstrom \& Sun, 2007), where the UK is a common-law country while France is a code-law country. Accounting standards in common-law countries, such as the UK, are constructed by independent professional bodies to meet the informational needs of capital market participants (Ball, Kothari, \& Robin, 2000). This is similar to the development of IFRS that essentially originate from UK domestic accounting standards (Christensen et al., 2013), which aim to provide capital market participants with relevant information for making economic decisions such as equity investments (Brüggemann et al., 
2013; Pope \& McLeay, 2011), i.e., low-divergence with respect to IFRS. In contrast, accounting standards in code-law countries, such as France, are constructed by governments in order to meet their own demands regarding commercial laws and taxation (Soderstrom \& Sun, 2007), i.e., high-divergence with respect to IFRS. In light of the preceding arguments, we expect IFRS adoption to have a greater impact on aspects of SEOs among high-divergence firms compared to low-divergence firms (Hong et al., 2014). Furthermore, we discuss potential confounding factors that might drive our findings at the end of this section.

We hypothesize that the mandatory adoption of IFRS serves to reduce the level of earnings management prior to issuing SEOs among high-divergence firms. As discussed in section 2.2, prior studies find that firms manage their earnings upwardly before issuing SEOs (Rangan, 1998; Shivakumar, 2000; Teoh et al., 1998), keeping in mind that earnings management activities increase under higher levels of asymmetric information (Schipper, 1989; Warfield et al., 1995). If IFRS mitigate information asymmetry (Daske et al., 2008) and improve accounting quality (Barth et al., 2008), then we expect IFRS adoption to deter earnings management prior to issuing SEOs, when managerial incentives to inflate earnings are high (Teoh et al., 1998). As such, we formulate the following testable hypothesis:

H1: Following IFRS adoption, there is a greater reduction in the level of earnings management prior to issuing SEOs among high-divergence firms than low-divergence firms.

The information shock caused by IFRS adoption is expected to increase financial statements informative-ness due to the following: (1) mandated increase in disclosure volume (Ball, $\mathrm{Li}, \&$ Shivakumar, 2015), (2) improved timeliness and transparency (Brüggemann et al., 2013), (3) 
enhanced financial reporting quality (Barth et al., 2008), and (4) improved financial statement comparability (DeFond, $\mathrm{Hu}, \mathrm{Hung}, \& \mathrm{Li}, 2011$ ). Hence, the main relationship between IFRS and SEOs arises from the assumption that IFRS are expected to mitigate information asymmetry relating to assets in place and, therefore, improve the market reaction to SEOs (Myers \& Majluf, 1984). Based on the preceding arguments, we establish the hypothesis below:

H2: Following IFRS adoption, there is a greater improvement in the market reaction to SEO announcements among high-divergence firms than low-divergence firms.

Finally, Eckbo et al. (2007) document that the rarity of SEOs is attributed to the high costs associated with this kind of corporate financing. Supportive evidence is provided by Hovakimian \& Hutton (2010) who find that firms that receive a better market reaction to their first SEO are more likely to issue a subsequent SEO. If the market reaction to SEO announcements improves following IFRS adoption, then the associated cost with equity financing is reduced and, accordingly, we expect managers to issue SEOs more frequently. Therefore, we construct the following hypothesis:

H3: Following IFRS adoption, there is a greater increase in the propensity to issue SEOs among high-divergence firms than low-divergence firms.

Nevertheless, in order to ascribe capital benefits to IFRS per se, we have to ensure that other factors associated with accounting quality did not change at the same time. For instance, if accounting standards were better enforced after IFRS adoption in France, then our findings 
would be driven by better enforcement and not by IFRS implementation (Christensen, Hail, \& Leuz, 2013; Leuz \& Wysocki, 2016). Brown et al. (2014) construct an international index for the enforcement of accounting standards in 2002, 2005 and 2008. The index shows that the enforcement of accounting standards in France did not increase around IFRS and was similar to the enforcement in the UK, which improves the comparability between both groups. This suggests that the improvements in the information environment of high-divergence firms should not be attributed to the enforcement factor, but to the improvement in accounting standards. Another factor that might confound our predictions about the effect of IFRS adoption is the change in the level of corporate governance. Prior studies find that firms with a better corporate governance enjoy a better market reaction to SEOs because investors are less worried about ex post moral hazards (Kim \& Purnanandam, 2014). Katelouzou \& Siems (2015) document that the levels of corporate governance and investor's protection in the UK and France are similar and sticky over the time period we cover, which diminishes the possibility for the aforementioned factors to confound the impact of IFRS adoption.

\section{Research Methodology}

We test our hypotheses using a difference-in-differences research design. The low-divergence sample (UK firms) serves as the benchmark group and the high-divergence sample (French firms) serves as the study group. An ideal benchmark group would be a set of French firms with comparable characteristics but not subject to IFRS adoption. However, it is not possible to create such a benchmark group since IFRS adoption is mandatory for all listed firms. The purpose of our existing research design choice is to simultaneously (i) minimize the institutional environment differences and (ii) maximize the pre-IFRS divergence in accounting standards between the benchmark and study groups. This helps us identify the differential impact of 
changes in accounting standards while holding institutional environment broadly comparable between the two groups (Leuz, 2003). Furthermore, to the extent IFRS adoption affects UK firms in similar ways to their French counterparts, it will only bias against, rather than in favor, of finding empirical evidence consistent with our hypotheses.

We denote the IFRS adoption period using the dummy variable POST that takes the value 1 if the year is 2005 or beyond, and 0 otherwise. We differentiate the high-divergence sample from the low-divergence sample using the dummy variable HIGHDIV that takes the value 1 if the firm is listed in France, and 0 otherwise. We identify the difference-in-differences estimator from the interaction between POST and HIGHDIV. The interaction term POST*HIGHDIV takes the value 1 if the firm is listed in the high-divergence country between 2005 and 2008, and 0 otherwise.

\subsection{Test of earnings management}

To test the change in earnings management prior to issuing SEOs, we mainly follow Lobo and Zhou (2010) and Iliev (2008) in developing the earnings management model as shown in equation (1). The dependent variable $D A C C$ is discretionary accruals, calculated in the most recent financial year prior to issuing an SEO. We calculate discretionary accruals following the modified cross-sectional Jones (1991) model as described in Dechow, Sloan, \& Sweeney (1995). The procedure for calculating discretionary accruals is explained in detail in Appendix B. We deflate variables by the average of total assets prior to IFRS in order to isolate the fair value adjustment effect on total assets after IFRS; yet our findings remain unchanged when deflating by total assets in year t-1. Initially, the time period used for this test is 2001 till 2008; however, we exclude year 2005 from this regression because SEOs that were issued in 2005 had their discretionary accruals in 2004 (i.e., before IFRS). We also exclude the first year from the preIFRS period (i.e., 2001) in order to keep a balance between pre- and post-IFRS. As such, the 
time period for the earnings management regression starts in 2002 and ends in 2008, excluding 2005.

We include control variables that proxy for firm size using LOGTA (Burgstahler \& Dichev, 1997), financial leverage using $L E V$ (DeFond \& Jiambalvo, 1994; Sweeney, 1994), investment opportunities using TOBINQ (Kasznik, 1999), tangibility using TANG (Herrmann, Inoue, \& Thomas, 2003), loss-making firms using LOSS (Burgstahler \& Dichev, 1997), change in income using $\triangle I N C D U M$ (Lobo \& Zhou, 2006), operating cash flow and audit quality using $O C F$ and BIG4DUM (Becker et al., 1998). In addition, we add a measure for real earnings management, $R E M$. Real earnings management is an alternative way for manipulating earnings which might be utilized by firms in order to inflate earnings prior to issuing SEOs (Cohen \& Zarowin, 2010). ${ }^{3}$ We calculate the proxy for real earnings management following Cohen, Dey, \& Lys (2008) as shown in Appendix B. Moreover, Owens et al. (2017) theorize that idiosyncratic economic shocks affect the measurement of abnormal accruals, and this effect is more prominent when considering the absolute value of abnormal accruals. They find a strong association between the proxy for economic shocks and absolute abnormal accruals, which is a part of our analysis. Thus, we calculate the proxy for idiosyncratic economic shocks IDSHOCK following Owens et al. (2017) and include it in equation (1). Finally, we add dummy variables in order to control for the offering technique of SEOs (RIGHTDUM, PLACDUM ${ }^{4} \&$ PUBLICDUM).

$$
\begin{aligned}
\text { DACC }= & \alpha_{0}+\alpha_{1} \text { POST }+\alpha_{2} \text { HIGHDIV }+\alpha_{3} \text { POST } * H I G H D I V^{*} \\
& +\sum \alpha_{i} \text { Controls }_{i}+\sum \alpha_{j} \text { Year FE } E_{j}+\sum \alpha_{k} \text { Industry FE } E_{k}+\varepsilon
\end{aligned}
$$

\footnotetext{
${ }^{3}$ Ipino \& Parbonetti (2016) find that the reduction in accrual earnings management following IFRS adoption is offset by an increase in real earnings management. Their finding is prominent for EU countries with strong enforcement of IFRS. Therefore, we must control for real earnings management when testing the change in accrual earnings management following IFRS adoption.

${ }^{4}$ The Placements dummy variable (PLACDUM) always goes to the intercept and will not appear in the tables.
} 


\subsection{Test of SEO market reaction}

In order to test the difference in the market reaction to issuing SEOs following IFRS, we follow Kim \& Purnanandam (2014) since their setting is similar to ours. They study the difference in the market reaction to SEOs under different corporate governance conditions in the US. The dependent variable in equation (2) is the cumulative abnormal returns $C A R[-2,+2]$ using a [$2,+2]$ window around the announcement date; our results hold when changing the event window to $[-1,+1]$ or to $[0,+1]$. Following prior studies, we use the filing date provided by SDC Platinum as the announcement date of SEOs (Dissanaike, Faasse, \& Jayasekera, 2014; Fauver et al., 2017; Kim \& Purnanandam, 2014); this maintains a level of comparability with prior studies that use the same data source. ${ }^{5}$ We estimate normal returns using the EVENTUS default market model regression over a [-11, -261] window (Dissanaike et al., 2014). Note that the significance of our results persists when using the adjusted market model estimates. For UK firms, we use FTSE All-Share and Dow Jones STOXX600 market indices as a benchmark for market returns. ${ }^{6}$ For French firms, we use SBF120 and Dow Jones STOXX600 market indices as a benchmark for market returns.

Equation (2) includes control variables that proxy for the size of the issue using LOGISSUE (Clinton, White, \& Woidtke, 2014; Kraser, 1986), growth opportunities using TOBINQ (DeAngelo, DeAngelo, \& Stulz, 2010; Denis, 1994), investment opportunities using RND (Kim \& Purnanandam, 2014), firm size using LOGTA (Barnes \& Walker, 2006), financial leverage using LEV (Lee \& Masulis, 2009), profitability using ROA (Teoh et al., 1998), tangibility using

\footnotetext{
${ }^{5}$ Any possible inaccuracies in the data source is a limitation shared across existing studies. This creates an opportunity for future studies to reexamine the existing inferences when a better data source becomes available.

${ }^{6}$ The STOXX Europe 600 Index is derived from the STOXX Europe Total Market Index (TMI) and is a subset of the STOXX Global 1800 Index. With a fixed number of 600 components, the STOXX Europe 600 Index represents large, mid and small capitalization companies across 18 countries of the European region: Austria, Belgium, Czech Republic, Denmark, Finland, France, Germany, Greece, Ireland, Italy, Luxembourg, the Netherlands, Norway, Portugal, Spain, Sweden, Switzerland and the United Kingdom.
} 
TANG (Lyandres, Sun, \& Zhang, 2008), cash liquidity using LIQDT (DeAngelo et al., 2010), operating risk using SDEBIT (Gaud, Jani, Hoesli, \& Bender, 2005), dividend-paying status using DIVDUM (Booth \& Chang, 2011), information asymmetry about the issue using DAYS (Dittmar $\&$ Thakor, 2007), ${ }^{7}$ and loss-making firms using LOSS. Finally, we include dummy variables in order to control for the offering technique of the SEO (RIGHTDUM, PLACDUM \& PUBLICDUM).

$$
\begin{aligned}
\text { CAR }[-2,+2]= & \beta_{0}+\beta_{1} \text { POST }+\beta_{2} \text { HIGHDIV }+\beta_{3} \text { POST } * H I G H D I V \\
& +\sum \beta_{i} \text { Controls }_{i}+\sum \beta_{j} \text { Year FE }_{j}+\sum \beta_{k} \text { Industry FE }_{k}+\varepsilon
\end{aligned}
$$

\subsection{Test of propensity to issue equity}

After examining the change in earnings management prior to issuing SEOs and the change in the market reaction to announcing these SEOs, we move on to test the change in the propensity to issue new equity following IFRS. In order to test for such a change, we follow Hovakimian \& Hutton (2010) who examine the propensity to issue new SEOs for the second time depending on the post-issue returns after the first SEO. The dependent variable in equation (3) is the dummy variable SEODUM that takes the value 1 in case the firm issues one or more SEOs in a specific year, and 0 otherwise. We include control variables that proxy for firm size using LOGTA, growth opportunities using $R N D$, and investment opportunities using TOBINQ (Dittmar \& Thakor, 2007). We also proxy firm's tangibility using $T A N G$ and financial leverage using $L E V$ (Rajan \& Zingales, 1995). We finally control for profitability using ROA (Eckbo et al., 2007), cash liquidity using LIQDT (Dittmar \& Thakor, 2007), dividend-paying status using DIVDUM

\footnotetext{
${ }^{7}$ Dittmar \& Thakor (2007) state that information asymmetry around SEO announcements is higher when the date of the SEO is far from the last earnings announcement.
} 
(Booth \& Chang, 2011). All variables in equation (3) are defined in Appendix A, and mainly follow Hovakimian \& Hutton (2010).

$$
\begin{aligned}
\text { SEODUM }= & \gamma_{0}+\gamma_{1} \text { POST }+\gamma_{2} \text { HIGHDIV }+\gamma_{3} \text { POST } * \text { HIGHDIV } \\
& +\sum \gamma_{i} \text { Controls }_{i}+\sum \gamma_{j} \text { Year FE } E_{j}+\sum \gamma_{k} \text { Industry } F E_{k}+\varepsilon
\end{aligned}
$$

\section{Data and Descriptive Statistics}

\subsection{Sample construction}

In order to identify the impact of IFRS on aspects of SEOs, we choose two European countries that are similar in aspects that are likely to affect financial reporting while having different domestic accounting standards prior to adopting IFRS. We argue that the UK and France are highly comparable capital markets that satisfy the assumptions of the geographic regression discontinuity research design described in Keele, Titiunik, \& Zubizarreta (2015). We label the UK as a low-divergence country and France as a high-divergence country. As mentioned earlier, the rationale behind our sample selection is the high comparability between the UK and France in various aspects. The selected countries have similar economic, institutional and political factors. These factors might confound with the effect of IFRS adoption if they were different between both groups (Leuz, 2003). The similarity in these factors between the selected countries is the main advantage of our restricted sample selection over international studies. At the country level, both markets have relatively comparable sizes (World Bank, 2014), similar enforcement of accounting standards around IFRS adoption (Brown et al., 2014), comparable investor protection (Katelouzou \& Siems, 2015), and both countries did not allow voluntary adoption of IFRS (Leuz \& Wysocki, 2016). At the corporate level, both markets have relatively comparable ownership 
dispersion (Enriques \& Volpin, 2007) and similar scores for corporate governance (Katelouzou \& Siems, 2015). ${ }^{8}$ Appendix D includes a comprehensive comparison of institutional factors that might confound the intended effects of IFRS adoption. ${ }^{9}$ To draw some qualitative inference from Appendix D, we first select four main institutional variables that are likely to confound the effect of IFRS adoption in equity markets: audit and enforcement quality (Brown et al., 2014), rule of law (Kaufmann, Kraay, \& Mastruzzi, 2007), shareholder's protection (Katelouzou \& Siems, 2015), and disclosure requirements by securities laws (La Porta, Lopez-De-Silanes, \& Shleifer, 2006). We then sort all countries by the aforementioned variables. The UK and France fall in the same quartile/quantile for all selected variables, which suggests that both countries are relatively similar in their institutional factors. Therefore, the main relevant change around 2005 is the implementation of IFRS, which supports using a difference-in-differences research design.

The sample period starts in 2001 and ends in 2008 (Hail et al., 2014). ${ }^{10}$ The data source for equity offerings is Thomson ONE (SDC Platinum), for financial variables is Worldscope, and for stock returns is Datastream. We download all seasoned equity offerings in the UK and France, consisting of Placements, Rights and Public Offerings. ${ }^{11}$ We apply data restrictions following Hong et al. (2014) as described in Appendix C. Specifically, we drop financial firms, nonordinary/secondary shares, firms that did not adopt IFRS in 2005, and firms that do not appear at least once in pre- and post-IFRS periods. The final sample consists of 645 issuing firms in the

\footnotetext{
${ }^{8}$ Compared to other Western European countries, like Germany, the UK and France have the closest scores for ownership dispersion and corporate governance.

${ }^{9}$ Appendix D is constructed from different studies that discuss institutional factors, at the country and the corporate levels, which might affect financial reporting quality and market reactions to equity issuance. In some instances, we include governance scores for other countries, such as Germany and Italy, to enhance comparison/benchmarking.

${ }^{10}$ As a sensitivity check, we run the regressions after excluding the observations of year 2008 because it is the beginning of the Global Financial Crisis. In addition, we run the regressions after excluding the observations of year 2005 as it is considered a transitional year with high level of information asymmetry (Wang \& Welker, 2011). Our inferences remain unchanged when excluding year 2008 and/or year 2005 from the sample period.

${ }^{11}$ After applying the sample selection criteria described in Appendix C, we were left with only 4 public offerings in France. For this reason we excluded public offerings from the high-divergence sample as we cannot run our statistical analyses based on 4 observations.
} 
UK with 1100 SEOs and 100 issuing firms in France with 135 SEOs. Given missing financial variables, the main regression includes 922 SEOs in the UK and 127 in France. Out of the 127 SEOs in France, we hand-collect financial variables for 33 issues using Thomson ONE Fundamentals. $^{12}$

\subsection{Descriptive statistics}

We begin the presentation of the descriptive statistics by including two graphs that show the change in discretionary accruals before SEOs, and the change in the market reaction to SEO announcements, over the sample period. Figure 1 shows the change in the level of average discretionary accruals prior to SEO announcements for low-divergence and high-divergence firms between 2002 and 2008, excluding 2005. Figure 1 demonstrates how discretionary accruals significantly decrease among high-divergence firms after 2005. On the other hand, no similar change in discretionary accruals takes place among low-divergence firms.

[Insert Figure 1 here]

With respect to the change in the market reaction to SEO announcements, Figure 2 shows an increase in the average market reaction to SEOs among high-divergence firms after 2005. However, the change in the average market reaction to SEOs among low-divergence firms after 2005 is minor. The interesting point demonstrated in Figure 1 is that the average market reaction of high-divergence firms becomes similar to that of low-divergence firms after 2005, with a similar pattern over the years.

\section{[Insert Figure 2 here]}

Panel A Table 1 reports the distribution of the distinct types of equity offerings between 2001 and 2008. The low-divergence sample consists of Rights, Placements and Public Offerings,

\footnotetext{
${ }^{12}$ Knowing that the hand-collection of data is very time consuming, we only hand-collect financial data for issues in France because the high-divergence sample is small while the low-divergence sample is relatively big.
} 
whereas the high-divergence sample does not include Public Offerings. The distribution of SEOs is balanced for both samples across the years except for low-divergence firms in 2007 and 2008, when the number of issued placements increases remarkably. This increase in the number of placements is attributed to the scarcity of financial resources during the Global Financial Crisis around 2008.

Panel B Table 1 reports summary statistics for cumulative abnormal returns around SEO announcements for the low-divergence and high-divergence samples, pre- and post-IFRS. The panel shows that the market reaction to SEO announcements is positive for the low-divergence sample before IFRS adoption, and stays positive afterwards. On average, for the low-divergence sample, $C A R[-2 ;+2]$ is $0.0154(0.0175)$ with a t-statistic of 5.95 (8.02) before (after) IFRS adoption. On the other hand, for the high-divergence sample, the market reaction to SEO announcements before IFRS adoption is negative and becomes positive following IFRS adoption. On average, for the high-divergence sample, CAR [-2; +2] is $-0.0081(0.0174)$ with a tstatistic of -2.48 (4.69) before (after) IFRS adoption. Finally, we report the differences in $C A R[-2 ;+2]$ for all offering techniques between pre- and post-IFRS periods. The differences in $C A R[-2 ;+2]$ for all the offering techniques in the low-divergence sample are statistically insignificant whereas the corresponding differences in the high-divergence sample are statistically significant at the $5 \%$ level.

[Insert Table 1 here]

Panel A and Panel B Table 2 report summary statistics for the variables used in equations (1) and (2), respectively, along with the statistical significance of the difference in means between low-divergence and high-divergence samples. Panel A shows that the mean of DACC is (insignificantly) larger for high-divergence firms than low-divergence firms (0.0462 vs 0.0385). 
This suggests that, on average, high-divergence firms engage more in earnings management activities than low-divergence firms around SEOs. Panel B shows that the average market reaction to SEOs is significantly more positive for low-divergence firms over the sample period. This is because the market reaction around SEOs for the high-divergence sample is negative before 2005 .

On average, low-divergence firms are smaller in size (LOGTA), are less reliant on debt (LEV), have higher investment opportunities (TOBINQ), are more tangible (TANG), have more cash liquidity (LIQDT), spend more on research and development $(R N D)$, pay less dividends (DIVDUM), are less profitable (LOSS and ROA) and engage more in real earnings management activities $(R E M)$ than high-divergence firms.

[Insert Table 2 here]

\section{Main Results}

In this section, we first describe the results of testing the three main hypotheses where IFRS adoption contributes to: (1) reduce the level of earnings management prior to SEOs, (2) improve the market reaction to SEO announcements and (3) increase the propensity to issue new SEOs. Then, for robustness checks, we discuss how we attempt to control for changes in economics as well as for potential self-selection bias.

\subsection{Earnings management around SEOs}

In Table 3, we report two sets of results where the first set has $D A C C$ as the dependent variable and the second set has $A B S D A C C$ as the dependent variable. In each set of the two, we run three OLS regressions using the low-divergence sample, the high-divergence sample, and the full sample. The obtained results do not represent the whole capital market in the UK and France 
since the selected sample only includes firms that issue SEOs. Thus, we do not expect the coefficients on the control variables to be perfectly consistent with the earnings management literature. The coefficient on $L E V$ is negative and significant across all the regressions in the first set. This might be due to the fact that firms that are highly leveraged are more scrutinized by creditors and subject to higher accountability; therefore, such firms are hesitant to engage in earnings management activities. The coefficient on LIQDT is negative for both samples, suggesting that firms that are short on cash engage more in earnings management. In principle, firms that issue equity are either suffering financial distress or raising funds to finance their investments. If a firm is not short on cash but still issues equity, then this firm is probably raising external funds to finance a profitable project. This explains the negative coefficient on TOBINQ, which indicates that firms with a better growth opportunity do not need to engage in earnings management prior to raising external equity. As expected, the coefficient on $\triangle I N C D U M$ is positive and significant across all the regressions in the first set. This is consistent with Lobo \& Zhou (2010) who find a strong association between positive changes in net income and earnings management. Finally, the dummy variables that control for the SEO offering technique show that firms engage less in earnings management prior to Right issues compared to Placement issues. ${ }^{13}$

With respect to our main result, the first column of Table 3 shows that the coefficient on POST for the low-divergence group is insignificant. This supports our claim that IFRS adoption is expected to have a minor effect on the financial reporting environment in the UK. On the other hand, the second column of Table 3 shows a significantly negative coefficient on POST for the high-divergence group, suggesting that IFRS adoption serves to restrain earnings management activities prior to issuing SEOs among high-divergence firms. This conclusion holds when

\footnotetext{
${ }^{13}$ The estimates for PLACDUM go to the constant and the negative coefficients on RIGHTDUM suggest that firms manage earnings more (less) before issuing Placements (Rights). In addition, the coefficients on PUBLICDUM are insignificant.
} 
replacing the signed discretionary accruals with the absolute value of discretionary accruals, $A B S D A C C$. As shown in the second set of the regressions (the last three columns of Table 3), the coefficient on POST is insignificant for the low-divergence sample but significantly negative for the high-divergence sample, with a significant difference-in-differences coefficient. Therefore, we reject the null hypothesis of $\mathrm{H} 1$ in favor of the alternative. It is noteworthy that these results hold when controlling for real earnings management, an alternative way for manipulating earnings prior to issuing SEOs (Cohen \& Zarowin, 2010).

In an unreported analysis, we follow Owens et al. (2017) and control for idiosyncratic economic shocks. Owens et al. (2017) state that accrual models wrongly assume firm stationarity and intra-industry homogeneity. They argue that the accruals generating process differs between firms operating in the same industry, and also differs for the same firm over time, due to changes in the firm's economics. Therefore, when calculating the firm's discretionary accruals as the abnormal accruals relative to the average industry-year accruals, we should account for idiosyncratic economic shocks. They conclude that idiosyncratic economic shocks affect the measurement of abnormal accruals, where this effect becomes a serious concern when considering the absolute value of abnormal accruals. Our results confirm the conclusion of Owens et al. (2017) as the difference-in-differences coefficient for the unsigned discretionary accruals regression $(A B S D A C C)$ becomes insignificant after including the proxy for idiosyncratic economic shock (IDSHOCK). Yet, the difference-in-differences coefficient for the signed discretionary accruals regression $(D A C C)$ remains significant even while including IDSHOCK. Therefore, our conclusion regarding the effect of IFRS adoption on the level of earnings management remains unchanged after controlling for possible changes in firms' economics. ${ }^{14}$

\footnotetext{
${ }^{14}$ Although our time period is relatively short, yet we run an additional test to check for the effect of a time trend. Specifically, we run the same regression of equation (1) while excluding all years after IFRS adoption and replacing
} 
[Insert Table 3 Here]

\subsection{Market reaction to SEOS}

Table 4 reports regression results for the market reaction model depicted in equation (2). The first three columns include regression results for the low-divergence sample, the high-divergence sample and the full sample, respectively. The coefficient on LOGTA in all regressions shows that investors react more negatively to SEOs by larger firms, probably because such firms are more scrutinized by the public. The coefficient on $R O A$ in all regressions shows that more profitable firms experience a better market reaction to their issued equity. The coefficient on LIQDT shows that firms with higher cash liquidity receive a more negative market reaction to their SEOs since more cash availability increases the probability of moral hazard. The coefficient on $L E V$ in all regressions shows that more leveraged firms receive a better market reaction to their equity issues. Yet, the coefficients mentioned so far are statistically insignificant. The coefficient on TANG shows a significantly negative impact on cumulative abnormal returns in all regressions. That is, more tangible firms receive a significantly more negative market reaction. Finally, in regards to offering techniques, Public Offerings receive a significantly higher market reaction among low-divergence firms.

The main variable of interest, POST, shows that there is no significant effect for IFRS adoption among low-divergence firms (t-statistic $=0.41)$. On the other hand, the coefficient on POST in the second column shows that IFRS adoption has a significantly positive effect on $C A R[-2 ;+2]$ among high-divergence firms. The estimate on POST shows that the market

the dummy variable POST with a new dummy variable (call it Pseudo) that takes the value 1 for years $2003 / 2004$ and the value of zero for the year 2002. We repeat the same test while assigning the new dummy Pseudo the value 1 for the year 2004 and the value of zero for years 2002/2003. The coefficient on Pseudo is insignificant in both regressions, meaning that our results are not attributed to the time trend effect. 
reaction has improved by an average of $2.6 \%$ after the implementation of IFRS in the highdivergence country. Moreover, the interaction term, POST*HIGHDIV, shows that the differencein-differences estimate is $2.34 \%$ and is statistically significant at the $1 \%$ level. That is, the change in the market reaction among high-divergence firms improves by $2.34 \%$ relative to the change in the market reaction among low-divergence firms following IFRS adoption. Therefore, we reject the null hypothesis of $\mathrm{H} 2$ in favor of its alternative. ${ }^{15}$

In the last two columns of Table 4 we test the significance of the difference-in-differences estimates for Rights and Placements issues. The coefficient on POST*HIGHDIV in the last two columns of Table 4 shows that the change in the market reaction among high-divergence firms, for Rights and Placements, respectively, improves significantly by $3 \%$ and $1.84 \%$ compared to the corresponding change in the market reaction among low-divergence firms. In relation to information asymmetry, Placements are usually issued to existing investors who are better informed about the firm (Cronqvist \& Nilsson, 2005), unlike Rights that are issued to both new and existing investors. Therefore, if IFRS were to mitigate information asymmetry, and consequently diminish the gap between informed and uninformed investors, then we would expect a greater effect for IFRS where the information gap is bigger. This expectation is met by the higher impact of IFRS on the market reaction to Rights compared to Placements. In the same vein, Ginglinger et al. (2013) find that the market reaction to Rights issues in France is remarkably negative due to their higher illiquidity. The coefficient on HIGHDIV in the last two columns of Table 4 shows that, prior to IFRS adoption, high-divergence firms received a more negative market reaction to Rights compared to Placements. The fact that the improvement in the

\footnotetext{
${ }^{15} \mathrm{We}$ also test for the time trend effect through running the regression of equation (2) for years prior to IFRS. We include the Pseudo dummy variable which takes the value 1 for years 2003/2004 and zero for years 2001/2002. The coefficient on Pseudo is insignificant, suggesting that our results are not attributed to the time trend effect.
} 
market reaction among high-divergence firms is greater for Rights compared to Placements supports our argument that IFRS have a greater effect where information asymmetry is higher.

In conclusion to this section, we find support for our hypothesis that IFRS adoption serves to mitigate information asymmetry and improve the market reaction to issuing SEOs in the highdivergence country compared to the low-divergence country.

$$
\text { [Insert Table } 4 \text { Here] }
$$

\subsection{Propensity to issue new equity}

After showing that IFRS adoption improves the market reaction to SEO announcements and therefore facilitates equity financing, we test the change in the propensity to issue new equity. We first examine the change in the propensity to issue SEOs using the full time period (i.e. 20012008) as shown in the first three columns in Table 5. The results from the marginal effects of the logistic regressions show that the propensity to issue SEOs increases after IFRS adoption among low-divergence and high-divergence firms; yet the increase among high-divergence firms is double the increase among low-divergence firms. This yields an insignificant difference-indifferences estimate. Nevertheless, the summary statistics in Table 1 show that the number of Placements issued by low-divergence firms increase remarkably in 2007/2008, i.e., when the Global Financial Crisis struck. Thus, we repeat our test while excluding years 2007/2008 to eliminate the Global Financial Crisis effect and years 2001/2002 to keep the dataset balanced. The fourth column of Table 5 shows that, for the low-divergence sample, the significance of IFRS adoption disappears after excluding years 2007/2008. On the other hand, the fifth column of the same table shows that, for the high-divergence sample, the significance of IFRS adoption remains after excluding years 2007/2008. The last column of Table 5 shows that the differencein-differences estimate (POST*HIGHDIV) is statistically significant at the $1 \%$ level. This 
suggests that IFRS adoption serves to facilitate equity financing and increase the propensity to issue new equity among high-divergence firms compared to low-divergence firms. Therefore, we reject the null hypothesis of $\mathrm{H} 3$ in favor of the alternative.

[Insert Table 5 Here]

\subsection{Robustness checks}

The robustness checks we perform mainly aim to control for: (1) probable changes in the underlying economics of French firms and (2) potential self-selection bias. We partially control for changes in economics through assigning each high-divergence observation a matching lowdivergence observation. We use Coarsened Exact Matching (Iacus et al., 2012) based on total assets, industry, and the IFRS period (Barth et al., 2008). ${ }^{16}$ Moreover, we control for potential selection bias in the market reaction model (equation 2) using the Heckman (1979) two-step model. Table 6 reports results from the sensitivity checks for equations (1), (2), and (3) as discussed below.

The first column of Table 6 reports regression results for the difference-in-differences regression of equation (1) using the matched sample. The results show that the coefficient on $P O S T^{*} H I G H D I V$ is still significantly negative after performing the matched-sample analysis for the earnings management test. This supports our initial finding that IFRS adoption serves to reduce earnings management activities prior to SEOs in the high-divergence country. Similarly, the second column of Table 6 reports regression results for the difference-in-differences regression of equation (2) using the matched sample. The results show that the difference-indifferences estimate is still significantly positive when using the matched sample. The third column of Table 6 reports results for the robustness test that attempt to control for a potential

\footnotetext{
${ }^{16}$ Ideally, we would match based on years; however, given that SEOs are not frequent enough, we match highdivergence observations pre/post IFRS to low-divergence observations in the same period.
} 
self-selection bias in the market reaction model since firms issue SEOs voluntarily and, therefore, select themselves into the sample (Booth \& Chang, 2011; Lennox, Francis, \& Wang, 2012). We employ the full sample in this regression and use the Heckman (1979) two-step model to control for potential self-selection bias as described in what follows. First, we run a probit model, using issuing and non-issuing firms in the UK and France, with a dependent dummy variable that takes the value 1 if the firm has announced an SEO (and zero otherwise). We follow Kim \& Purnanandam (2014) and select SALES as the exclusion restriction (instrument), because sales are more likely to affect the decision of announcing SEOs (selection equation) but less likely to affect the cumulative abnormal returns (observation equation). Then, we calculate the Inverse Mills Ratio (IMR) from the probit regression. Finally, we run the OLS regression of equation (2) while including IMR. The results reported in the third column of Table 6 shows that the significance of the coefficient on $P O S T^{*} H I G H D I V$ still holds. The joint results from the matched-sample regression (second column) and the Heckman two-step model (column 3) provide a sensitivity check to our finding that IFRS adoption contributes to improving the market reaction to issuing SEOs in the high-divergence country. Finally, the last column of Table 6 reports the marginal effects of the difference-in-differences logistic regression of equation (3) using the matched sample. Interestingly, after matching observations from both samples and using the full time period, the coefficient on $P O S T^{*} H I G H D I V$ is significantly positive. This result suggests that, when comparing similar sized firms, operating in the same industry, the propensity to issue new equity significantly increases among high-divergence firms compared to low-divergence firms. Hence, we reinforce the rejection of the null hypothesis of H3 in favor of the alternative.

[Insert Table 6 Here] 
We perform an additional three unreported sensitivity checks. First, we test the change in the market reaction using the same sample used in testing the change in earnings management. This is meant to ensure a level of consistency across the reported tests by showing that the observed effects apply to the same set of observations. Second, we cluster standard errors at the year level in order to control for potential serial correlation; we currently report White (1980) robust standard error given the small number of observations (Angrist \& Pischke, 2009). Third, we employ a different exclusion restriction in the Heckman (1979) selection model as the existing exclusion restriction (SALES) might be correlated with the deflator of the regression equation (total assets), which might render the existing exclusion restriction endogenous. Specifically, we use the percentage of firms that issue SEOs in the industry that the firm operates in (based on the Datastream industry classification 'INDM2'). The logic behind selecting this exclusion restriction is that firms operating in industries that witness frequent equity offerings have a higher probability to issue SEOs (Booth \& Chang, 2011), and this probability is not correlated with the deflator (total assets) and does not affect the dependent variable $C A R[-2 ;+2]$. Our results are robust to these sensitivity checks.

\section{Conclusions}

As in any study that evaluates the effect of a policy in capital markets, we cannot be certain that our findings are solely attributed to the enactment of this policy. Despite that we have designed our methodology to rule out other events that may have yielded our findings, yet our study is subject to some limitations. First, our findings could potentially be affected by the enactment of financial directives studied in Fauver et al. (2017) around the time of IFRS adoption. It would be ideal to study firms that are only affected by IFRS adoption but not by the directives. However, it is not possible to identify such firms given that the directives are also mandatory across firms. 
Nevertheless, to the extent the financial directives are expected to influence firms, one would expect the impact to be similar across UK and France since the enactment took place at the same time in both countries and given the similarity in their institutional environments. As such, our observation of differential effects on aspects of SEOs between the two countries lends support to the prediction that it is the influence of IFRS adoption rather than the financial directives. Second, given that the effectiveness of IFRS adoption partially relies on the level of legal enforcement, it is noteworthy that we do not expect to observe a similar effect for IFRS adoption in countries with weak legal enforcement even if they had different domestic accounting standards from IFRS. Third, despite the advantages of selecting the UK as a benchmark group as discussed in sections 3 and 4.1, yet our research design would have been more robust if we could have found a country which was economically similar to France that had not adopted IFRS in the sample period. Unfortunately no such country exists.

In this paper, we study whether and how changes in accounting standards affect corporate financing through SEOs. The mandatory adoption of IFRS in Europe in 2005 generates a positive shock to the corporate financial information environment, which is expected to mitigate information asymmetry (Hail, Tahoun, \& Wang, 2014). We employ a difference-in-differences research design where we select UK firms as the benchmark group and French firms as the study group. The reason for this selection is that we do not expect a significant effect of IFRS adoption on the financial reporting system in the UK since IFRS originated from the UK domestic accounting standards (Christensen et al., 2013). In stark contrast, IFRS adoption is expected to bring significant changes to the financial reporting system in France, where the domestic accounting standards differ materially from IFRS (Bae et al., 2008; Ding et al., 2007). As such, we refer to UK firms as low-divergence firms and to French firms as high-divergence firms. 
Despite this difference in their financial reporting systems pre-IFRS adoption, both countries have similar economic and institutional characteristics. The fact that the UK and France are comparable economically and institutionally provides some assurance that our findings are mainly attributable to the change in the financial reporting system following the IFRS mandate and not to other confounding effects associated with institutional characteristics, which prior studies argue that such characteristics could affect the economic consequences of IFRS adoption (Bonetti, Magnan, \& Parbonetti, 2016; Christensen et al., 2013; Daske, Hail, Leuz, \& Verdi, 2013).

The cornerstone of our theoretical argument is that the adoption of IFRS serves to mitigate information asymmetry. Given lower asymmetric information and enhanced accounting quality, we predict and find that, following IFRS, the level of earnings management activities around SEOs decreases among high-divergence firms compared to low-divergence firms. As a result of lower levels of earnings management and information asymmetry, we provide evidence indicating that the market reaction to issuing SEOs improves significantly among highdivergence firms following IFRS. The reduction of the costs associated with equity financing causes an increase in the propensity to issue new SEOs among high-divergence firms following IFRS. As a sensitivity check, we run a matched-sample analysis by matching high-divergence and low-divergence observations using Coarsened Exact Matching (CEM). In addition, we control for potential self-selection bias by using the Heckman (1979) two-step model. The results are insensitive either to CEM matching or to controlling for self-selection bias.

Despite the longstanding literature on the role of financial reporting in equity markets, more research needs to be undertaken to understand the channels through which the mandatory adoption of IFRS affects different aspects of SEOs. For instance, we find qualitative evidence 
that shows an increase in repeat issuers in France compared to the UK after 2005, which suggests that the favorable market reaction to SEOs following IFRS adoption in France has incentivized firms to issue more equity. On the other hand, we do not find significant changes in the type of SEOs issued, in the volume of the issue, or in the composition of the issuing firms by industries. Future studies can also investigate if negative earnings surprises are lower following SEOs (which is a result of an improved information environment), if financial analysts are more bullish in their forecasts on the issuing firms, and whether issuing firms shift from using accrual-based earnings management to real earnings management activities following IFRS adoption.

Overall, we contribute to the literature by showing how changing accounting standards could affect equity financing. Our findings suggest that when investors are better informed about the underlying value of the firm, the equity financing process becomes less costly. The main implication of our study is that a better financial reporting environment reduces information costs for investors and capital acquisition costs for firms in the capital market. 


\section{Acknowledgements}

We are grateful to Andrew Stark, Konstantinos Stathopoulos, Norman Strong, Nikolaos Tsileponis, Liang Xu (Alice), Cheng Zeng (Colin), as well as participants of the EAA Annual Congress 2017 at the University of Valencia and the BAFA 2014 doctoral colloquium at the University of Manchester for their useful comments. 


\section{References:}

André, P. (2017). The role and current status of IFRS in the completion of national accounting rules evidence from European countries. Accounting in Europe, 14(1-2), 1-12.

Angrist, J. D., \& Pischke, J.-S. (2009). Mostly Harmless Econometrics. Princeton University Press.

Armstrong, C., Barth, M., Jagolinzer, A., \& Riedl, E. (2010). Market Reaction to Events Surrounding the Adoption of IFRS in Europe Market Reaction to Events Surrounding the Adoption of IFRS in Europe. The Accounting Review, 85(1), 31-61.

Bae, K.-H., Tan, H., \& Welker, M. (2008). International GAAP differences: The impact of foreign analysts. The Accounting Review, 83(3), 593-628.

Ball, R., Kothari, S. P., \& Robin, A. (2000). The effect of international institutional factors on properties of accounting earnings. Journal of Accounting and Economics, 29(1), 1-51.

Ball, R., Li, X., \& Shivakumar, L. (2015). Contractibility of financial statement information prepared under IFRS : Evidence from debt contracts. Journal of Accounting Research, 53(5).

Barnes, E., \& Walker, M. (2006). The seasoned-equity issues of UK firms: Market reaction and issuance method choice. Journal of Business Finance and Accounting, 33(1-2), 45-78.

Barth, M., Landsman, W., \& Lang, M. (2008). International accounting standards and accounting quality. Journal of Accounting Research, 46(3), 467-498.

Becker, C., Defond, M., Jiambalvo, J., \& Subramanyam, K. R. (1998). The Effect of Audit Quality on Earnings Management. Contemporary Accounting Research, 15(1).

Bonetti, P., Magnan, M. L., \& Parbonetti, A. (2016). The influence of country- and firm-level governance on financial reporting quality: Revisiting the evidence. Journal of Business Finance \& Accounting, 43(9-10), 1059-1094.

Booth, L., \& Chang, B. (2011). Information asymmetry, dividend status, and seo announcement-day returns. The Journal of Financial Research, XXXIV(1), 155-177.

Brown, P., Preiato, J., \& Tarca, A. (2014). Measuring Country Differences in Enforcement of Accounting Standards: An Audit and Enforcement Proxy. Journal of Business Finance and Accounting, 41(1-2), $1-52$.

Brüggemann, U., Hitz, J.-M., \& Sellhorn, T. (2013). Intended and Unintended Consequences of Mandatory IFRS Adoption: A Review of Extant Evidence and Suggestions for Future Research. European Accounting Review, 22(1), 1-37.

Burgstahler, D., \& Dichev, I. (1997). Earnings management to avoid earnings decreases and losses. Journal of Accounting and Economics, 24, 99-126.

Callao, S., \& Jarne, J. I. (2010). Have IFRS affected earnings management in the European Union. Accounting in Europe, 7(2), 159-189.

Cascino, S., Clatworthy, M., García Osma, B., Gassen, J., Imam, S., \& Jeanjean, T. (2014). Who uses financial reports and for what purpose? Evidence from capital providers. Accounting in Europe, 11(2), 185-209.

Christensen, H., Hail, L., \& Leuz, C. (2013). Mandatory IFRS Reporting and Changes in Enforcement. Journal of Accounting and Economics, 56(2), 147-177.

Christensen, H., Lee, E., Walker, M., \& Zeng, C. (2015). Incentives or Standards: What Determines Accounting Quality Changes around IFRS Adoption? European Accounting Review, 24(1), 31-61.

Clinton, S., White, J., \& Woidtke, T. (2014). Differences in the Information Environment Prior to SEOs under Relaxed Disclosure Regulation. Journal of Accounting and Economics, 58(1), 59-78.

Cohen, D., Dey, A., \& Lys, T. (2008). Real and accrual-based earnings management in the pre- and postSarbanes-Oxley periods. The Accounting Review, 83, 757-787.

Cohen, D., \& Zarowin, P. (2010). Accrual-based and real earnings management activities around seasoned equity offerings. Journal of Accounting and Economics, 50(1), 2-19.

Corwin, S. (2003). The Determinants of Underpricing for Seasoned Equity Offers. Journal of Finance, $\operatorname{LVIII}(5), 2249-2279$.

Daske, H., Hail, L., Leuz, C., \& Verdi, R. (2008). Mandatory IFRS reporting around the world: Early evidence on the economic consequences. Journal of Accounting Research, 46(5), 1085-1142. 
Daske, H., Hail, L., Leuz, C., \& Verdi, R. (2013). Adopting a label: Heterogeneity in the economic consequences around IAS/IFRS adoptions. Journal of Accounting Research, 51(3), 495-547.

De George, E., Li, X., \& Shivakumar, L. (2016). A review of the IFRS adoption literature. Review of Accounting Studies, 21(3), 898-1004.

DeAngelo, H., DeAngelo, L., \& Stulz, R. (2010). Seasoned equity offerings, market timing, and the corporate lifecycle. Journal of Financial Economics, 95(3), 275-295.

Dechow, P., Sloan, R., \& Sweeney, A. (1995). Detecting Earnings Management. The Accounting Review, $70(2), 193-225$.

DeFond, M., Hu, X., Hung, M., \& Li, S. (2011). The impact of mandatory IFRS adoption on foreign mutual fund ownership: The role of comparability. Journal of Accounting and Economics, 51(3), 240-258.

DeFond, M., \& Jiambalvo, J. (1994). Debt Convenant Effects and the Manipulation of Accruals. Journal of Accounting and Economics, 17, 145-176.

Denis, D. (1994). Investment Opportunities and the Market Reaction to Equity Offerings. Journal of Financial and Quantitative Analysis, 29(2), 159-177.

Ding, Y., Hope, O.-K., Jeanjean, T., \& Stolowy, H. (2007). Differences between domestic accounting standards and IAS: Measurement, determinants and implications. Journal of Accounting and Public Policy, 26(1), 1-38.

Dissanaike, G., Faasse, J., \& Jayasekera, R. (2014). What do equity issuances signal? A study of equity issuances in the UK before and during the financial crisis. Journal of International Money and Finance, 49(PB), 358-385.

Dittmar, A., \& Thakor, A. (2007). Why Do Firms Issue Equity? The Journal of Finance, LXII(1-54).

Eckbo, E., Masulis, R., \& Norli, Ø. (2007). Security Offerings. Handbook of Empirical Corporate Finance SET, 2, 233-373.

Enriques, L., \& Volpin, P. (2007). Corporate Governance Reforms in Continental Europe. The Journal of Economic Perspectives, 117-140.

Ernstberger, J., Stich, M., \& Vogler, O. (2012). Economic consequences of accounting enforcement reforms: The case of Germany. European Accounting Review, 21(2), 217-251.

Fauver, L., Loureiro, G., \& Taboada, A. (2017). The impact of regulation on information quality and performance around seasoned equity offerings: International evidence. Journal of Corporate Finance, (Forthcoming).

Ginglinger, E., Matsoukis, L., \& Riva, F. (2013). Seasoned Equity Offerings: Stock Market Liquidity and the Rights Offer Paradox. Journal of Business Finance and Accounting, 40(1-2), 215-238.

Hail, L., Tahoun, A., \& Wang, C. (2014). Dividend payouts and information shocks. Journal of Accounting Research, 52(2), 403-456.

Heckman, J. (1979). Sample Selection Bias as a Specification Error. Econometrica, 47(1), 153-161.

Hong, H., Hung, M., \& Lobo, G. (2014). The Impact of Mandatory IFRS Adoption on IPOs in Global Capital Markets. The Accounting Review, 89(4), 1365-1397.

Horton, J., Serafeim, G., \& Serafeim, I. (2013). Does mandatory IFRS adoption improve the information environment? Contemporary Accounting Research, 30(1), 388-423.

Houqe, M. N., van Zijl, T., Dunstan, K., \& Karim, W. (2012). The Effect of IFRS Adoption and Investor Protection on Earnings Quality Around the World. International Journal of Accounting, 47(3), 333355.

Hovakimian, A., \& Hutton, I. (2010). Market Feedback and Equity Issuance: Evidence from Repeat Equity Issues. Journal of Financial and Quantitative Analysis, 45(03), 739-762.

Hribar, P., \& Collins, D. (2002). Errors in estimating accruals: implications for empirical research. Journal of Accounting Research, 40(1), 105-134.

Iliev, P. (2010). The Effect of SOX Section 404 Compliance on Audit Fees , Earnings Quality and Stock Prices *. The Journal of Finance, LXV(3), 1163-1196.

Ipino, E., \& Parbonetti, A. (2016). Mandatory IFRS adoption: the trade-off between accrual-based and real earnings management. Accounting and Business Research, 46(8), 1-31. 
Jones, J. (1991). Earnings Management during Import Relief Investigations. Journal of Accounting Research, 29(2), 193-228.

Kasznik, R. (1999). On the association between voluntary disclosure and earnings management. Journal of Accounting Research, 37, 57-81.

Katelouzou, D., \& Siems, M. (2015). Disappearing Paradigms in Shareholder Protection: Leximetric Evidence for 30 Countries. Journal of Corporate Law Studies, 15(1), 127-160.

Kaufmann, D., Kraay, A., \& Mastruzzi, M. (2007). Governance Matters VI: Aggregate and Individual Governance Indicators 1996-2006. Washington, DC.

Keele, L., Titiunik, R., \& Zubizarreta, J. (2015). Enhancing a geographic regression discontinuity design through matching to estimate the effect of ballot initiatives on voter turnout. Journal of the Royal Statistical Society: Series A (Statistics in Society), 178(1), 223-239.

Kim, E. H., \& Purnanandam, A. (2014). Seasoned equity offerings, corporate governance, and investments. Review of Finance, 18(3), 1023-1057.

Kraser, W. (1986). Stock price movements in response to stock issues under asymmetric information. The Journal of Finance, 41, 93-106.

La Porta, R., Lopez-De-Silanes, F., \& Shleifer, A. (2006). What Works in Securities Laws? The Journal of Finance, 61(1), 1-32. http://doi.org/10.1111/j.1540-6261.2006.00828.x

La Porta, R., Lopez-De-Silanes, F., Shleifer, A., \& Vishny, R. (1998). Law and Finance. Journal of Political Economy, 106(6), 1113-1155.

Landsman, W., Maydew, E., \& Thornock, J. (2012). The information content of annual earnings announcements and mandatory adoption of IFRS. Journal of Accounting and Economics, 53(1-2), $34-54$.

Lang, M., \& Lundholm, R. (2000). Voluntary Disclosure and Equity Offerings: Reducing Information Asymmetry or Hyping the Stock? Contemporary Accounting Research, 17(4), 623-662.

Lee, G., \& Masulis, R. (2009). Seasoned Equity Offerings: Quality of Accounting Information and Expected Flotation Costs. Journal of Financial Economics, 92(3), 443-469.

Leone, A., Rock, S., \& Willenborg, M. (2007). Disclosure of intended use-of-proceeds and underpricing in initial public offering. Journal of Accounting Research, 45(1), 111-153.

Leuz, C. (2003). IAS versus U.S. GAAP: Information asymmetry-based evidence from Germany's New Market. Journal of Accounting Research, 41(3), 445-472.

Leuz, C., \& Wysocki, P. (2016). The Economics of Disclosure and Financial Reporting Regulation: Evidence and Suggestions for Future Research. Journal of Accounting Research, 54(2), 525-622.

Li, X., \& Yang, H. (2016). Mandatory financial reporting and voluntary disclosure: The effect of mandatory IFRS adoption on management forecasts. The Accounting Review, 91(3), 933-953.

Lobo, G., \& Zhou, J. (2006). Did Conservatism in Financial Reporting Increase after the Sarbanes-Oxley Act and CEO/CFO Certification of Financial Statements? Accounting Horizons, 20(1), 57-73.

Lobo, G., \& Zhou, J. (2010). Changes in Discretionary Financial Reporting Behavior Following the Sarbanes-Oxley Act. Journal of Accounting, Auditing \{\&\} Finance, 25(1), 1-26.

Lyandres, E., Sun, L., \& Zhang, L. (2008). The New Issues Puzzle: Testing the Investment-Based Explanation. The Review of Financial Studies, 21(6), 2825-2855.

McLean, D., Pontiff, J., \& Watanabe, A. (2009). Share issuance and cross-sectional returns: International evidence. Journal of Financial Economics, 94(1), 1-17.

Muller, K., Riedl, E., \& Sellhorn, T. (2011). Mandatory Fair Value Accounting and Information Asymmetry: Evidence from the European Real Estate Industry. Management Science, 57(6), 11381153.

Myers, S., \& Majluf, N. (1984). Corporate financing and investment decisions when firms have information that investors do not have'. Journal of Financial Economics, 12, 187-221.

Owens, E., Wu, J. S., \& Zimmerman, J. (2017). Idiosyncratic Shocks to Firm Underlying Economics and Abnormal Accruals. The Accounting Review, 92(2), 183-219.

Pope, P., \& McLeay, S. (2011). The European IFRS experiment: objectives, research challenges and some early evidence. Accounting and Business Research, 41(3), 233-266. 
Rajan, R., \& Zingales, L. (1995). What do we know about capital structure? Some evidence from international data. The Journal of Finance, 50, 1421-1460.

Rangan, S. (1998). Earnings management and the performance of seasoned equity offerings. Journal of Financial Economics, 50(1), 101-122.

Rock, K. (1986). Why new issues are underpriced. Journal of Financial Economics, 15, 187-212.

Roychowdhury, S. (2006). Earnings management through real activities manipulation. Journal of Accounting and Economics, 42, 335-370.

Schipper, K. (1989). Commentary on Earnings Management. Accounting Horizons, 3(4), 91-102.

Shivakumar, L. (2000). Do firms mislead investors by overstating earnings before seasoned equity offerings? Journal of Accounting and Economics, 29(3), 339-371.

Soderstrom, N., \& Sun, K. J. (2007). IFRS Adoption and Accounting Quality: A Review. European Accounting Review, 16(4), 675-702.

Sweeney, A. (1994). Debt Convenant Violations and Managers' Accounting Resposes. Journal of Accounting and Economics, 17, 281-308.

Teoh, S. H., Welch, I., \& Wong, T. J. (1998). Earnings management and the underperformance of seasoned equity offerings. Journal of Financial Economics, 50(1), 63-99.

Wang, S., \& Welker, M. (2011). Timing Equity Issuance in Response to Information Asymmetry Arising from IFRS Adoption in Australia and Europe. Journal of Accounting Research, 49(1), 257-307.

Warfield, T., Wild, J., \& Wild, K. (1995). Managerial ownership, accounting choices, and informativeness of earnings. Journal of Accounting and Economics, 20(1), 61-91.

White, H. (1980). A Heteroskedasticity-Consistent Covariance Matrix Estimator and a Direct Test for Heteroskedasticity. Econometrica, 48(4).

World Bank. (2014). GDP at market prices. Retrieved from http://data.worldbank.org/indicator/NY.GDP.MKTP.CD 


\section{Appendix A: Variable Definitions (sorted alphabetically)}

\begin{tabular}{|c|c|}
\hline Variable & Definition \\
\hline$A B S D A C C$ & $\begin{array}{l}\text { Absolute value of discretionary accruals in the most recent financial year prior to the } \\
\text { offering, deflated by the average of total assets in years prior to IFRS adoption. } \\
\text { Discretionary accruals are calculated following the modified cross-sectional Jones } \\
\text { (1991) model as described in Dechow et al (1995). See Appendix B for details. }\end{array}$ \\
\hline$\triangle I N C D U M$ & $\begin{array}{l}\text { Dummy variable that equals one if the change in net income is positive, and } 0 \\
\text { otherwise. }\end{array}$ \\
\hline$B I G 4 D U M$ & $\begin{array}{l}\text { Dummy variable that takes the value } 1 \text { if the firm is being audited by one of the big } \\
\text { four auditors, and } 0 \text { otherwise. }\end{array}$ \\
\hline$C A R[-2,+2]$ & $\begin{array}{l}\text { Cumulative abnormal return over a }[-2 ;+2] \text { window around the announcement day. } \\
\text { The variable is calculated using the default market model used by EVENTUS over a } \\
{[-11,-261] \text { window. We use two market indices for each country. For UK firms we }} \\
\text { use the FTSE All-Share and the STOXX EUROPE } 600 \text { E-PRICE INDEX indices. } \\
\text { For French firms we use the SBF120 (Société des Bourses Françaises } 120 \text { Index) and } \\
\text { the STOXX EUROPE } 600 \text { E-PRICE INDEX indices. }\end{array}$ \\
\hline$D A C C$ & $\begin{array}{l}\text { Discretionary accruals in the most recent financial year prior to the offering, deflated } \\
\text { by the average of total assets in years prior to IFRS adoption. Discretionary accruals } \\
\text { are calculated following the modified cross-sectional Jones (1991) model as } \\
\text { described in Dechow et al (1995). See Appendix B for details. }\end{array}$ \\
\hline$D A Y S$ & $\begin{array}{l}\text { Number of days between the SEO announcement date and the end of the most recent } \\
\text { earnings announcement. }\end{array}$ \\
\hline DIVDUM & Dummy variable that takes the value 1 if the firm pays dividends, and 0 otherwise. \\
\hline HIGHDIV & Dummy variable that takes the value 1 if the firm is listed in France, and 0 otherwise. \\
\hline IDSHOCK & $\begin{array}{l}\text { Proxy for idiosyncratic economic shocks, defined as the firm-specific stock return } \\
\text { variation in year } t \text { and year } t-1 \text {. It is computed as the mean squared errors of the } \\
\text { residuals from the regression of the firm's monthly return on monthly industry return } \\
\text { and monthly market return using } 2 \text { years of monthly data (year } t \text { and year } t-1 \text { ). }\end{array}$ \\
\hline POST & $\begin{array}{l}\text { Dummy variable that takes the value } 1 \text { if the year is greater than or equal } 2005 \text {, and } 0 \\
\text { otherwise. }\end{array}$ \\
\hline$L E V$ & $\begin{array}{l}\text { Total liabilities in the most recent financial year prior to the offering, deflated by the } \\
\text { average of total assets in years prior to IFRS adoption. }\end{array}$ \\
\hline$L I Q D T$ & $\begin{array}{l}\text { Total available cash balance in the most recent financial year prior to the offering } \\
\text { deflated by the average of total assets in years prior to IFRS adoption. }\end{array}$ \\
\hline LOGISSUE & $\begin{array}{l}\text { Natural logarithm of the total amount of the equity issued using seasoned equity } \\
\text { offerings. }\end{array}$ \\
\hline LOGTA & Natural logarithm of total assets in the most recent financial year prior to the offering. \\
\hline LOSS & $\begin{array}{l}\text { Dummy variable that takes the value } 1 \text { if the firm reports a loss in the most recent } \\
\text { financial year prior to the offering, and } 0 \text { otherwise. }\end{array}$ \\
\hline$O C F$ & $\begin{array}{l}\text { Operating cash flow in the most recent financial year prior to the offering deflated by } \\
\text { the average of total assets in years prior to IFRS adoption. }\end{array}$ \\
\hline
\end{tabular}




\begin{tabular}{|c|c|}
\hline PUBLICDUM & $\begin{array}{l}\text { Dummy variable that takes the value } 1 \text { if the offering technique is a public offering, } \\
\text { and } 0 \text { otherwise. }\end{array}$ \\
\hline PLACDUM & $\begin{array}{l}\text { Dummy variable that takes the value } 1 \text { if the offering technique is a placement issue, } \\
\text { and } 0 \text { otherwise. }\end{array}$ \\
\hline$R E M$ & $\begin{array}{l}\text { Proxy for real earnings management in the most recent financial year prior to the } \\
\text { offering, deflated by the average of total assets in years prior to IFRS adoption. Real } \\
\text { earnings management is calculated as described in (Cohen \& Zarowin, 2010). See } \\
\text { Appendix B for details. }\end{array}$ \\
\hline RIGHTDUM & $\begin{array}{l}\text { Dummy variable that takes the value } 1 \text { if the offering technique is a right issue, and } 0 \\
\text { otherwise. }\end{array}$ \\
\hline$R N D$ & $\begin{array}{l}\text { Research and development expenses in the most recent financial year prior to the } \\
\text { offering, deflated by the average of total assets in years prior to IFRS adoption. } \\
\text { Missing values of this variable are replaced with zeros. }\end{array}$ \\
\hline$R O A$ & $\begin{array}{l}\text { Net income before extraordinary items reported in the most recent financial year prior } \\
\text { to the offering, deflated by the average of total assets in years prior to IFRS adoption. }\end{array}$ \\
\hline SALES & Total sales, scaled by the average of total assets in years prior to IFRS adoption. \\
\hline$S D E B I T$ & $\begin{array}{l}\text { Standard deviation of earnings before interest and tax (EBIT), scaled by the average } \\
\text { of total assets in years prior to IFRS adoption. }\end{array}$ \\
\hline SEODUM & $\begin{array}{l}\text { Dummy variable that takes the value } 1 \text { if the firm issues an SEO in a particular year, } \\
\text { and zero in other years. }\end{array}$ \\
\hline$T A N G$ & $\begin{array}{l}\text { Total of property, plant and equipment in the most recent financial year prior to the } \\
\text { offering deflated by the average of total assets in years prior to IFRS adoption. }\end{array}$ \\
\hline TOBINQ & $\begin{array}{l}\text { Firm's market value in the most recent financial year prior to the offering, deflated by } \\
\text { the average of total assets in years prior to IFRS adoption; where market value is the } \\
\text { sum of total liabilities and market capitalization (stock price*outstanding shares). } \\
\text { Market value is retrieved directly from Datastream. }\end{array}$ \\
\hline
\end{tabular}




\section{Appendix B: Calculation of DACC and REM}

\section{Appendix B.1: Discretionary Accruals (DACC)}

In order to estimate discretionary accruals, we use the modified cross-sectional Jones (1991) model as described in (Hribar \& Collins, 2002). The modified Jones model is estimated by each country-industryyear separately, where the industry classification is based on the Datastream variable 'INDM2'. First, we run the regression model below:

$T A C C_{i l} / T A_{i}=b_{1}\left(1 / T A_{i}\right)+b_{2} \Delta S A L E S_{i l} / T A_{i}+b_{3} P P E_{i l} / T A_{i}+e_{i t}$

Where:

$T A C C_{i t}=N I B X-O C F$, where $N I B X$ is net income before extraordinary items and $O C F$ is operating cash flow (Hribar \& Collins, 2002).

$T A_{i}=$ average of total assets in years prior to IFRS adoption,

$\triangle S A L E S_{i t}=$ change in revenues,

$P P E_{i t}=$ property, plant and equipment.

Then, the estimates of $b_{1}, b_{2}$, and $b_{3}$ obtained from the cross-sectional regressions are used to estimate discretionary accruals as follows:

$D A C C_{i t}=T A C C_{i l} / T A_{i}-\left[\hat{b}_{1}\left(1 / T A_{i}\right)+\hat{b}_{2}\left(\Delta S A L E S_{i t}-\triangle R E C_{i t}\right) / T A_{i}+\hat{b}_{3} P P E_{i l} / T A_{i}\right]$

Where:

$\triangle R E C=$ change in receivables.

\section{Appendix B.2: Real Earnings Management (REM)}

We follow (Roychowdhury, 2006) in constructing the proxy for real earnings management since they study accrual and real earnings management around SEOs. The proxy comprises three components: (a) abnormal level of operating cash flow, (b) abnormal level of production costs, and (3) abnormal level of discretionary expenses.

We first generate the normal levels of operating cash flow, production costs, and discretionary expenses using the equations below (Roychowdhury, 2006). We run the regressions by each countryindustry-year separately, where the industry classification is based on the Datastream variable 'INDM2'.

Operating cash flow $(O C F)$ is a linear function of sales (SALES) and change in sales $(\triangle S A L E S)$. In order to estimate the normal level of operating cash flow, we run the model below:

$O C F_{i l} / T A_{i}=b_{1}\left(1 / T A_{i}\right)+b_{2} S A L E S_{i /} / T A_{i}+b_{3} \Delta S A L E S_{i /} / T A_{i}+e_{i t}$

The firm's abnormal $O C F$ is the actual $O C F$ minus the estimated normal $O C F$.

Production cost $(P R O D)$ is the sum of cost of goods sold $(C O G S)$ plus change in inventory $(\triangle I N V)$. Cost of goods sold $(C O G S)$ is a linear function of sales (SALES). Change in inventory $(\triangle I N V)$ is a linear function of lagged and current change in sales $(\triangle S A L E S)$. In order to estimate the normal level of production cost, we run the model below:

$\operatorname{PROD}_{i /} / T A_{i}=b_{1}\left(1 / T A_{i}\right)+b_{2} S_{A L E S} / T A_{i}+b_{3} \Delta S A L E S_{i /} / T A_{i}+b_{4} \Delta S A L E S_{i t-1} / T A_{i}+e_{i t}$ 
The firm's abnormal PROD is the actual PROD minus the estimated normal PROD.

Finally, discretionary expenses $(D I S X)$ are defined as the sum of (1) research and development expenses $(R N D)$ and (2) general, selling and administrative expenses $(S G A) .{ }^{17}$ Discretionary expenses are a linear function of lagged sales. In order to estimate the normal level of discretionary expenses, we run the model below:

$D I S X_{i \ell} / T A_{i}=b_{1}\left(1 / T A_{i}\right)+b_{2} S A L E S_{i t-1} / T A_{i}+e_{i t}$

The firm's abnormal DISX is the actual DISX minus the estimated normal DISX.

\section{Appendix C: Sample Construction}

The construction of the SEO sample in the UK and France between 2001 and 2008. The data is retrieved from SDC Platinum (Thomson ONE). All exclusions are detailed below.

\begin{tabular}{llll}
\hline & UK & France & All \\
Initial sample & 1609 & 185 & 1794 \\
Exclude financial firms & $(383)$ & $(34)$ & $(417)$ \\
Exclude non-ordinary/secondary shares & $(32)$ & $(4)$ & $(36)$ \\
Exclude firms that did not adopt IFRS in 2005 & $(71)$ & $(9)$ & $(81)$ \\
Exclude firms that do not appear pre- and post-IFRS & $(23)$ & $(3)$ & $(26)$ \\
\hline Final sample & 1100 & 135 & 1235 \\
\hline \hline
\end{tabular}

${ }^{17}$ Selling, general and administrative expenses (SGA) include advertising expenses, which are a part of discretionary expenses according to Roychowdhury (2006) and Cohen and Zarowin (2010). The variable code in WorldScope is WC01101. 


\section{Appendix D: Comparison of Institutional Factors in the UK and France (alphabetically)}

Brown et al. (2014): Audit and enforcement (2002, 2005, \& 2008)

\begin{tabular}{l|ccc|ccc}
\hline & \multicolumn{3}{|c|}{ France } & \multicolumn{3}{c}{ UK } \\
\hline Year & 2002 & 2005 & 2008 & 2002 & 2005 & 2008 \\
\hline Audit (maximum = 32) & 15.00 & 29.00 & 29.00 & 18.00 & 32.00 & 32.00 \\
Enforcement (maximum = 24) & 19.00 & 19.00 & 16.00 & 14.00 & 22.00 & 22.00
\end{tabular}

Enriques \& Volpin (2007): Ownership concentration (1995)

Percentage of widely held public firms

Percentage of average family control among public firms

Median largest voting block among public firms

\begin{tabular}{|c|c|c|c|}
\hline France & UK & Germany & Italy \\
\hline $60 \%$ & $100 \%$ & $50 \%$ & $20 \%$ \\
$20 \%$ & $0 \%$ & $10 \%$ & $15 \%$ \\
$20 \%$ & $10 \%$ & $57 \%$ & $55 \%$
\end{tabular}

Kaufmann, Kraay, \& Mastruzzi (2007): Country-level governance (2004, 2005, \& 2006)

\begin{tabular}{l|ccc|ccc}
\hline & \multicolumn{3}{|c|}{ France } & \multicolumn{3}{c}{ UK } \\
\hline Voice and accountability & 2004 & 2005 & 2006 & 2004 & 2005 & 2006 \\
Political stability & 1.44 & 1.49 & 1.40 & 1.61 & 1.49 & 1.42 \\
Government effectiveness & 0.51 & 0.43 & 0.46 & 0.40 & 0.33 & 0.46 \\
Regulatory quality & 1.49 & 1.47 & 1.20 & 1.92 & 1.71 & 1.83 \\
Rule of law & 1.16 & 1.06 & 1.06 & 1.76 & 1.55 & 1.76 \\
Control of corruption & 1.41 & 1.33 & 1.31 & 1.73 & 1.63 & 1.73 \\
& 1.39 & 1.40 & 1.44 & 1.99 & 1.94 & 1.86
\end{tabular}

Katelouzou \& Siems (2015): Governance metrics (1996 \& 2012)

\begin{tabular}{l|cc|cc|cc|cc}
\hline & \multicolumn{2}{|c|}{ France } & \multicolumn{2}{c|}{ UK } & \multicolumn{2}{c|}{ Germany } & \multicolumn{2}{c}{ Italy } \\
\hline Year & 1996 & 2012 & 1996 & 2012 & 1996 & 2012 & 1996 & 2012 \\
\hline Shareholder's protection (maximum $=8.00)$ & 7.00 & 7.75 & 6.75 & 7.40 & 3.60 & 6.50 & 3.25 & 5.80 \\
Law enforcement (maximum = 2.00) & 1.45 & 1.45 & 1.55 & 1.70 & 1.55 & 1.65 & 1.00 & 0.40
\end{tabular}

La Porta, Lopez-De-Silanes, \& Shleifer (2006): Regulation of securities markets indicators (2000)

\begin{tabular}{l|c|c|c|c}
\hline & France & Code-law median & UK & Common-law median \\
\hline Disclosure requirements by securities laws & 0.75 & 0.45 & 0.83 & 0.78 \\
Investigative powers in case of violating securities laws & 1.00 & 0.64 & 1.00 & 0.75 \\
Criminal sanctions in case of violating securities laws & 1.00 & 0.32 & 1.00 & 0.57 \\
Public enforcement & 0.77 & 0.53 & 0.68 & 0.62
\end{tabular}


Figure 1. The change in the average discretionary accruals prior to SEO announcements

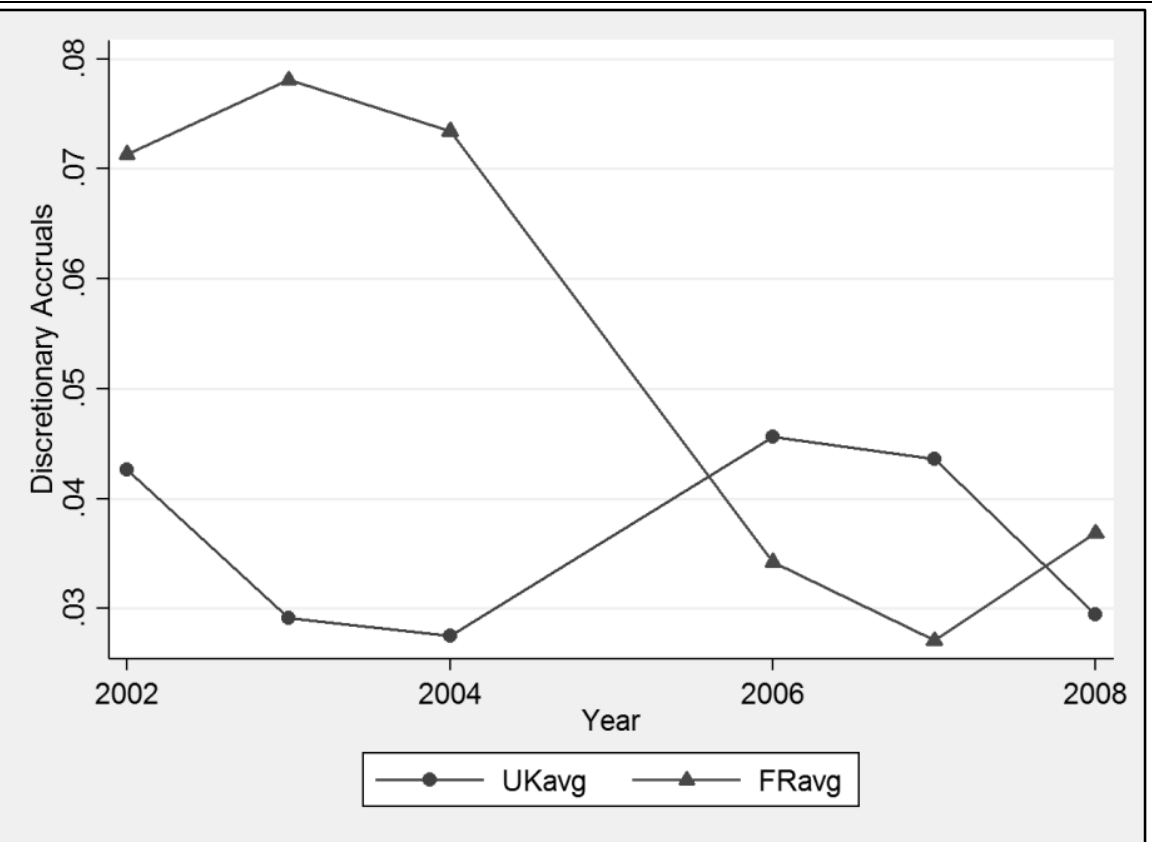

This figure shows the change in the average discretionary accruals prior to SEO announcements for low-divergence and high-divergence firms between 2002 and 2008, excluding 2005.

Figure 2. The change in the average cumulative abnormal returns around SEO announcements

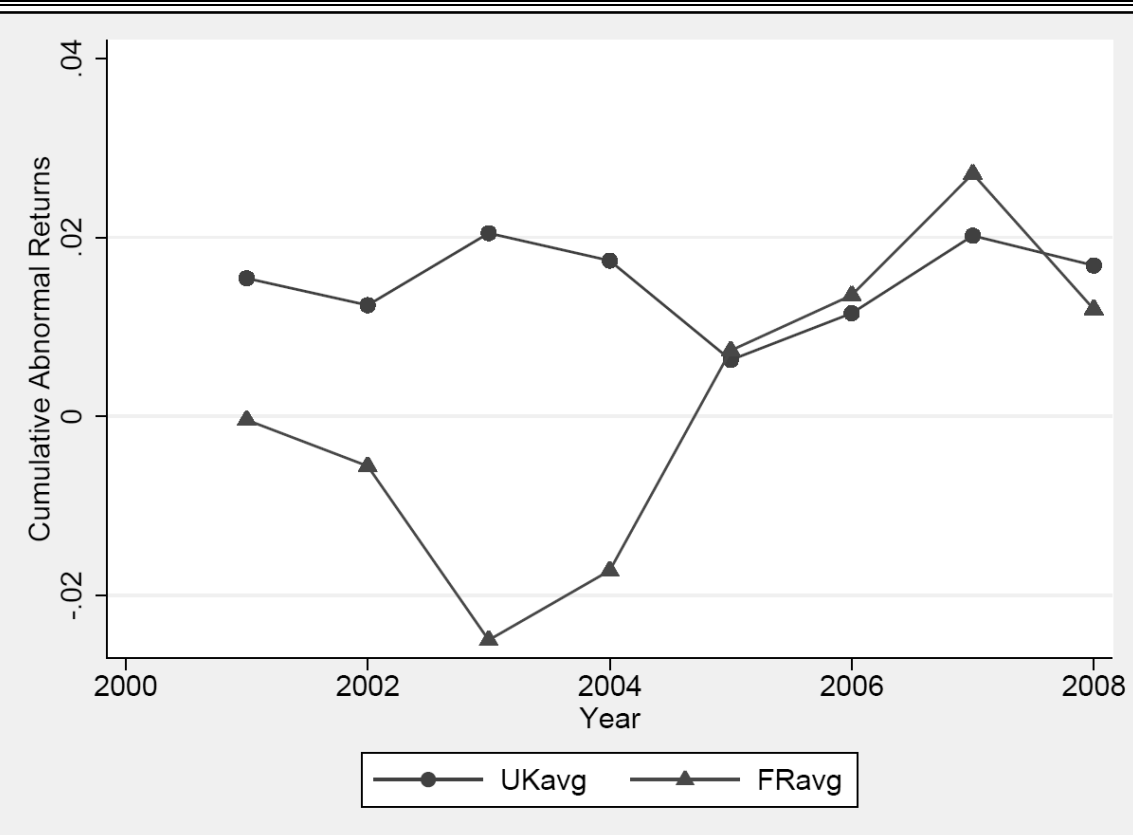

This figure shows the change in the average cumulative abnormal returns around SEO announcements for lowdivergence and high-divergence firms between 2001 and 2008. 
Table 1. Summary statistics for SEOs

Panel A: The annual distribution of SEOs

\begin{tabular}{|c|c|c|c|c|c|}
\hline \multirow[b]{2}{*}{ Year } & \multicolumn{3}{|c|}{ Low-divergence } & \multicolumn{2}{|c|}{ High-divergence } \\
\hline & Rights & Placements & Public Offerings & Rights & Placements \\
\hline 2001 & 13 & 127 & 15 & 8 & 12 \\
\hline 2002 & 12 & 26 & 14 & 7 & 2 \\
\hline 2003 & 9 & 33 & 20 & 8 & 2 \\
\hline 2004 & 15 & 29 & 15 & 5 & 2 \\
\hline 2005 & 21 & 33 & 3 & 13 & 2 \\
\hline 2006 & 10 & 74 & 2 & 9 & 7 \\
\hline 2007 & 2 & 195 & 6 & 15 & 9 \\
\hline 2008 & 2 & 243 & 3 & 13 & 13 \\
\hline Sub-total & 84 & 760 & 78 & 78 & 49 \\
\hline Grand-total & & 922 & & & \\
\hline
\end{tabular}

Panel B: Cumulative abnormal returns around SEOs pre- and post-IFRS

\begin{tabular}{|c|c|c|c|c|c|c|c|}
\hline \multirow[b]{2}{*}{ Offering Type } & \multicolumn{4}{|c|}{ Low-divergence } & \multicolumn{3}{|c|}{ High-divergence } \\
\hline & Rights & Placements & Public Offerings & All & Rights & Placements & All \\
\hline \multicolumn{8}{|l|}{ Pre-IFRS } \\
\hline $\mathrm{N}$ & 49 & 215 & 64 & 328 & 28 & 18 & 46 \\
\hline$C A R[-2 ;+2]$ & 0.0078 & 0.0127 & 0.0304 & 0.0154 & -0.0088 & -0.0070 & -0.0081 \\
\hline t-stat & 1.92 & 4.48 & 3.56 & 5.95 & -2.16 & -1.25 & -2.48 \\
\hline \multicolumn{8}{|l|}{ Post-IFRS } \\
\hline $\mathrm{N}$ & 35 & 545 & 14 & 594 & 50 & 31 & 81 \\
\hline$C A R[-2 ;+2]$ & 0.0050 & 0.0180 & 0.0258 & 0.0175 & 0.0178 & 0.0169 & 0.0174 \\
\hline t-stat & 1.2 & 7.83 & 1.33 & 8.02 & 4.4 & 2.33 & 4.69 \\
\hline $\begin{array}{l}\text { Diff: Post-Pre } \\
\text { (t-stat) }\end{array}$ & $\begin{array}{l}-0.0028 \\
(-0.36)\end{array}$ & $\begin{array}{c}0.0053 \\
(1.04) \\
\end{array}$ & $\begin{array}{c}-0.0046 \\
(-0.31)\end{array}$ & $\begin{array}{l}0.0021 \\
(0.24) \\
\end{array}$ & $\begin{array}{c}0.0266^{* * * *} \\
(4.45)\end{array}$ & $\begin{array}{c}0.0239^{* *} \\
(2.36)\end{array}$ & $\begin{array}{c}0.0255^{* * *} \\
(4.82)\end{array}$ \\
\hline
\end{tabular}

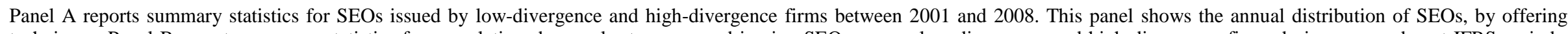

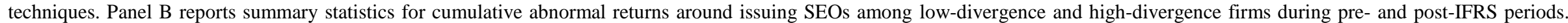

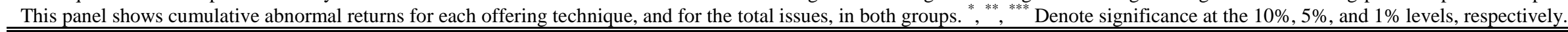


Table 2. Summary statistics for variables in equations (1) and (2)

Panel A: Summary statistics for variables used in equation (1)

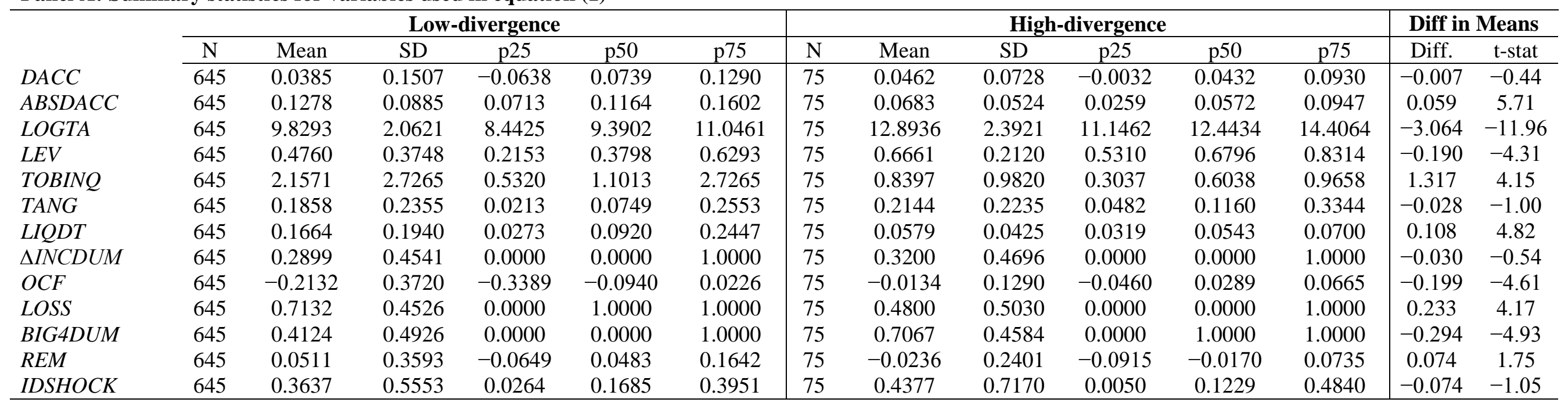

Panel B: Summary statistics for variables used in equation (2)

\begin{tabular}{|c|c|c|c|c|c|c|c|c|c|c|c|c|c|c|}
\hline & \multicolumn{6}{|c|}{ Low-divergence } & \multicolumn{6}{|c|}{ High-divergence } & \multicolumn{2}{|c|}{ Diff in Means } \\
\hline & $\mathrm{N}$ & Mean & $\mathrm{SD}$ & t-stat & p50 & p75 & $\mathrm{N}$ & Mean & $\mathrm{SD}$ & $\mathrm{p} 25$ & p50 & p75 & Diff. & t-stat \\
\hline $\operatorname{CAR}[-2 ;+2]$ & 922 & 0.0162 & 0.0491 & 0.0000 & 0.0000 & 0.0000 & 127 & 0.0073 & 0.0316 & 0.0000 & 0.0000 & 0.0084 & .009 & 1.98 \\
\hline LOGISSUE & 922 & 8.4337 & 2.2137 & 6.8459 & 8.4322 & 10.0344 & 127 & 10.6260 & 2.1774 & 9.0967 & 10.5000 & 12.1264 & -2.192 & -10.48 \\
\hline LOGTA & 922 & 9.9126 & 2.0595 & 8.4591 & 9.5178 & 11.1163 & 127 & 12.6705 & 2.6057 & 10.9800 & 12.1382 & 14.3901 & -2.757 & -13.66 \\
\hline$L E V$ & 922 & 0.4620 & 0.3555 & 0.1980 & 0.3875 & 0.6347 & 127 & 0.6304 & 0.2343 & 0.5112 & 0.6653 & 0.7791 & -.168 & -5.18 \\
\hline$R O A$ & 922 & -0.2827 & 0.6356 & -0.4582 & -0.1169 & 0.0130 & 127 & -0.0613 & 0.2648 & -0.0705 & 0.0104 & 0.0358 & -.311 & -5.45 \\
\hline$T O B I N Q$ & 922 & 2.3082 & 3.3230 & 0.5371 & 1.1454 & 2.8352 & 127 & 0.9678 & 1.2844 & 0.3031 & 0.6317 & 0.9658 & 1.340 & 4.49 \\
\hline$T A N G$ & 922 & 0.1987 & 0.2529 & 0.0225 & 0.0772 & 0.2727 & 127 & 0.2232 & 0.2511 & 0.0428 & 0.1065 & 0.3164 & -.024 & -1.02 \\
\hline$L I Q D T$ & 922 & 0.1634 & 0.1978 & 0.0257 & 0.0838 & 0.2282 & 127 & 0.0848 & 0.1328 & 0.0336 & 0.0616 & 0.0700 & .078 & 4.34 \\
\hline SDEBIT & 922 & 0.3994 & 2.2833 & 0.0611 & 0.1466 & 0.3197 & 127 & 0.2470 & 1.6831 & 0.0285 & 0.0595 & 0.1131 & .152 & 0.72 \\
\hline DIVDUM & 922 & 0.2049 & 0.4039 & 0.0000 & 0.0000 & 0.0000 & 127 & 0.4015 & 0.4921 & 0.0000 & 0.0000 & 1.0000 & -.196 & -4.99 \\
\hline$D A Y S$ & 922 & 191.4111 & 106 & 101 & 194 & 290 & 127 & 195.1575 & 98 & 107 & 193 & 278 & -3.746 & -0.37 \\
\hline LOSS & 922 & 0.7072 & 0.4553 & 0.0000 & 1.0000 & 1.0000 & 127 & 0.4173 & 0.4951 & 0.0000 & 0.0000 & 1.0000 & .289 & 6.65 \\
\hline
\end{tabular}

Panel A and Panel B report summary statistics for the variables used in equations (1) and (2), respectively. The time period for Panel A starts in 2002 and ends in 2008 (excluding 2005 ) whereas the time period for Panel B starts in 2001 and ends in 2008. All variables are defined in Appendix A. All continuous variables are winsorized at the $1 \%$ level to mitigate the influence of outliers. 
Table 3. The change in the signed/absolute discretionary accruals before issuing SEOs following IFRS adoption (H1)

\begin{tabular}{|c|c|c|c|c|c|c|}
\hline & Low-divergence & High-divergence & All & Low-divergence & High-divergence & All \\
\hline & $D A C C$ & $D A C C$ & $D A C C$ & $A B S D A C C$ & $A B S D A C C$ & $A B S D A C C$ \\
\hline \multirow[t]{2}{*}{ POST } & 0.0004 & $-0.0667^{* * *}$ & -0.0006 & -0.0015 & $-0.0496^{* * *}$ & -0.0028 \\
\hline & $(0.03)$ & $(-3.54)$ & $(-0.04)$ & $(-0.16)$ & $(-3.39)$ & $(-0.30)$ \\
\hline \multirow[t]{2}{*}{ HIGHDIV } & & & $0.0824^{* * * *}$ & & & -0.0219 \\
\hline & & & $(3.29)$ & & & $(-1.16)$ \\
\hline \multirow[t]{2}{*}{ POST $^{*}$ HIGHDIV } & & & $-0.0961^{* * *}$ & & & $-0.0351^{* *}$ \\
\hline & & & $(-3.80)$ & & & $(-2.07)$ \\
\hline \multirow[t]{2}{*}{ LOGTA } & 0.0048 & -0.0043 & 0.0034 & -0.0043 & -0.0051 & $-0.0043^{*}$ \\
\hline & (1.18) & $(-0.85)$ & $(0.97)$ & $(-1.56)$ & $(-1.25)$ & $(-1.82)$ \\
\hline \multirow[t]{2}{*}{$L E V$} & $-0.0881^{* * *}$ & $-0.0984^{*}$ & $-0.0845^{\text {*** }}$ & $0.0389^{* * * *}$ & -0.0299 & $0.0377^{* * *}$ \\
\hline & $(-4.20)$ & $(-2.00)$ & $(-4.13)$ & (2.89) & $(-0.75)$ & $(2.89)$ \\
\hline \multirow[t]{2}{*}{ TOBINQ } & $-0.0097^{* *}$ & $-0.0383^{* * *}$ & $-0.0107^{* * *}$ & 0.0040 & -0.0070 & 0.0037 \\
\hline & $(-2.51)$ & $(-4.38)$ & $(-2.78)$ & $(1.16)$ & $(-1.10)$ & $(1.09)$ \\
\hline \multirow[t]{2}{*}{$T A N G$} & 0.0311 & 0.0023 & $0.0370^{*}$ & 0.0127 & 0.0087 & 0.0114 \\
\hline & (1.44) & $(0.07)$ & (1.86) & $(0.96)$ & $(0.35)$ & $(0.95)$ \\
\hline \multirow[t]{2}{*}{$L I Q D T$} & $-0.0870^{* *}$ & -0.1668 & $-0.0834^{* *}$ & 0.0426 & 0.2054 & 0.0412 \\
\hline & $(-2.23)$ & $(-0.78)$ & $(-2.16)$ & $(1.52)$ & (1.67) & (1.49) \\
\hline \multirow[t]{2}{*}{$\triangle I N C D U M$} & $0.0863^{* * * *}$ & $0.0464^{* *}$ & $0.0834^{* * *}$ & 0.0102 & $0.0320^{* *}$ & $0.0124^{*}$ \\
\hline & $(7.52)$ & $(2.62)$ & $(7.89)$ & $(1.27)$ & $(2.45)$ & $(1.67)$ \\
\hline \multirow[t]{2}{*}{$O C F$} & -0.0392 & -0.0487 & -0.0327 & 0.0245 & 0.0233 & 0.0238 \\
\hline & $(-1.55)$ & $(-0.65)$ & $(-1.33)$ & $(1.61)$ & $(0.48)$ & $(1.63)$ \\
\hline \multirow[t]{2}{*}{ LOSS } & $-0.0563^{* * *}$ & 0.0258 & $-0.0449^{* * * *}$ & -0.0044 & 0.0241 & -0.0011 \\
\hline & $(-4.18)$ & (1.19) & $(-3.78)$ & $(-0.52)$ & $(1.50)$ & $(-0.15)$ \\
\hline \multirow[t]{2}{*}{ BIG4DUM } & -0.0144 & -0.0186 & -0.0160 & -0.0143 & -0.0115 & $-0.0135^{*}$ \\
\hline & $(-1.03)$ & $(-0.89)$ & $(-1.29)$ & $(-1.64)$ & $(-0.77)$ & $(-1.73)$ \\
\hline \multirow[t]{2}{*}{ RIGHTDUM } & $-0.0520^{* * *}$ & $-0.0344^{* *}$ & $-0.0479^{* *}$ & 0.0045 & -0.0102 & -0.0004 \\
\hline & $(-2.06)$ & $(-2.41)$ & $(-2.53)$ & $(0.23)$ & $(-0.98)$ & $(-0.03)$ \\
\hline \multirow[t]{2}{*}{ PUBLICDUM } & -0.0129 & & -0.0157 & 0.0086 & & 0.0066 \\
\hline & $(-0.53)$ & & $(-0.65)$ & $(0.59)$ & & $(0.47)$ \\
\hline \multirow[t]{2}{*}{ REM } & 0.0166 & 0.0356 & 0.0162 & 0.0006 & 0.0205 & 0.0017 \\
\hline & $(0.74)$ & $(0.84)$ & $(0.75)$ & $(0.04)$ & $(0.70)$ & $(0.11)$ \\
\hline \multirow[t]{2}{*}{ Intercept } & $0.0953^{*}$ & $0.3362^{* * * *}$ & $0.1036^{*}$ & $0.1263^{* * *}$ & $0.2111^{* * *}$ & $0.1771^{* * * *}$ \\
\hline & $(1.96)$ & $(5.63)$ & $(1.95)$ & $(3.76)$ & (4.13) & $(5.45)$ \\
\hline Industry \& Year FE & Included & Included & Included & Included & Included & Included \\
\hline $\mathrm{N}$ & 645 & 75 & 720 & 645 & 75 & 720 \\
\hline Adjusted- $\mathrm{R}^{2}$ & $20.61 \%$ & $25.17 \%$ & $19.50 \%$ & $7.28 \%$ & $24.05 \%$ & $8.91 \%$ \\
\hline
\end{tabular}

This table presents results on the change in the signed/absolute discretionary accruals before issuing SEOs following IFRS adoption among lowdivergence and high-divergence firms between 2002 and 2008, excluding 2005, using a difference-in-differences research design. The first two columns report results from the OLS regressions of signed discretionary accruals on a set of firm characteristics and the IFRS dummy, using the low-divergence and the high-divergence samples respectively, between 2002 and 2008, excluding 2005. The third column reports the results from the OLS regression of signed discretionary accruals on a set of firm characteristics and the difference-in-differences dummies, using the full sample between 2002 and 2008 , excluding 2005. Column 4 and column 5 report results from the OLS regressions of absolute discretionary accruals on a set of firm characteristics and the IFRS dummy, using the low-divergence and the high-divergence samples respectively, between 2002 and 2008, excluding 2005. The last column reports the results from the OLS regression of absolute discretionary accruals on a set of firm characteristics and the difference-in-differences dummies, using the full sample between 2002 and 2008, excluding 2005. All variables are defined in Appendix A. All continuous variables are winsorized at the 1\% level to mitigate the influence of outliers. All regressions include year and industry fixed effects. The t-statistics, presented in parentheses below the coefficients, are calculated using White (1980) standard errors. ${ }^{*},{ }^{* *},{ }^{* * *}$ Denote significance at the $10 \%, 5 \%$, and $1 \%$ levels, respectively. 
Table 4. The change in the market reaction to issuing SEOs following IFRS adoption (H2)

\begin{tabular}{|c|c|c|c|c|c|}
\hline & Low-divergence & High-divergence & All & Rights & Placements \\
\hline & $C A R[-2,+2]$ & $C A R[-2,+2]$ & $C A R[-2,+2]$ & $C A R[-2,+2]$ & $C A R[-2,+2]$ \\
\hline POST & $\begin{array}{c}0.0014 \\
(0.41)\end{array}$ & $\begin{array}{c}0.0260^{* * *} \\
(4.23)\end{array}$ & $\begin{array}{c}0.0014 \\
(0.42)\end{array}$ & $\begin{array}{c}-0.0025 \\
(-0.35)\end{array}$ & $\begin{array}{c}0.0013 \\
(0.32)\end{array}$ \\
\hline HIGHDIV & & & $\begin{array}{c}-0.0175^{\text {**** }} \\
(-3.28)\end{array}$ & $\begin{array}{c}-0.0191^{* * *} \\
(-2.59)\end{array}$ & $\begin{array}{c}-0.0160^{* * *} \\
(-2.24)\end{array}$ \\
\hline POST $^{*} H I G H D I V$ & & & $\begin{array}{c}0.0234^{* * * *} \\
(3.60)\end{array}$ & $\begin{array}{c}0.0300^{* * * *} \\
(3.27)\end{array}$ & $\begin{array}{c}0.0184^{*} \\
(1.82)\end{array}$ \\
\hline LOGISSUE & $\begin{array}{c}0.0006 \\
(0.55)\end{array}$ & $\begin{array}{r}-0.0017 \\
(-0.97)\end{array}$ & $\begin{array}{c}0.0005 \\
(0.46)\end{array}$ & $\begin{array}{c}0.0025 \\
(1.00)\end{array}$ & $\begin{array}{c}0.0003 \\
(0.22)\end{array}$ \\
\hline LOGTA & $\begin{array}{c}-0.0012 \\
(-0.84)\end{array}$ & $\begin{array}{c}-0.0013 \\
(-0.69)\end{array}$ & $\begin{array}{c}-0.0013 \\
(-1.02)\end{array}$ & $\begin{array}{c}-0.0012 \\
(-0.65)\end{array}$ & $\begin{array}{c}-0.0024^{*} \\
(-1.77)\end{array}$ \\
\hline$L E V$ & $\begin{array}{c}0.0082 \\
(1.21)\end{array}$ & $\begin{array}{c}0.0082 \\
(0.63)\end{array}$ & $\begin{array}{l}0.0083 \\
(1.31)\end{array}$ & $\begin{array}{r}-0.0172 \\
(-1.30)\end{array}$ & $\begin{array}{c}0.0125^{* * *} \\
(2.08)\end{array}$ \\
\hline$R O A$ & $\begin{array}{l}0.0016 \\
(0.49)\end{array}$ & $\begin{array}{c}0.0042 \\
(0.13)\end{array}$ & $\begin{array}{c}0.0013 \\
(0.43)\end{array}$ & $\begin{array}{c}-0.0221^{* * *} \\
(-2.96)\end{array}$ & $\begin{array}{c}0.0036 \\
(1.04)\end{array}$ \\
\hline TOBINQ & $\begin{array}{c}-0.0005 \\
(-0.70)\end{array}$ & $\begin{array}{c}0.0029 \\
(1.28)\end{array}$ & $\begin{array}{c}-0.0004 \\
(-0.59)\end{array}$ & $\begin{array}{c}0.0019 \\
(0.65)\end{array}$ & $\begin{array}{c}-0.0006 \\
(-0.86)\end{array}$ \\
\hline$T A N G$ & $\begin{array}{c}-0.0155^{* * *} \\
(-2.62)\end{array}$ & $\begin{array}{c}-0.0305^{* *} \\
(-2.04)\end{array}$ & $\begin{array}{c}-0.0161^{* * *} \\
(-2.91)\end{array}$ & $\begin{array}{c}-0.0103 \\
(-1.16)\end{array}$ & $\begin{array}{c}-0.0167^{* * * *} \\
(-3.34)\end{array}$ \\
\hline$L I Q D T$ & $\begin{array}{c}-0.0038 \\
(-0.40)\end{array}$ & $\begin{array}{c}-0.0197 \\
(-0.88)\end{array}$ & $\begin{array}{c}-0.0024 \\
(-0.27)\end{array}$ & $\begin{array}{c}-0.0378^{* * *} \\
(-2.45)\end{array}$ & $\begin{array}{c}0.0001 \\
(0.01)\end{array}$ \\
\hline$R N D$ & $\begin{array}{c}0.0340 \\
(1.41)\end{array}$ & $\begin{array}{c}-0.0742^{*} \\
(-1.81)\end{array}$ & $\begin{array}{c}0.0282 \\
(1.25)\end{array}$ & $\begin{array}{c}-0.0068 \\
(-0.32)\end{array}$ & $\begin{array}{c}0.0177 \\
(0.81)\end{array}$ \\
\hline SDEBIT & $\begin{array}{c}-0.0004 \\
(-0.81)\end{array}$ & $\begin{array}{l}0.0007 \\
(0.15)\end{array}$ & $\begin{array}{c}-0.0004 \\
(-0.96)\end{array}$ & $\begin{array}{c}-0.0137^{* * * *} \\
(-3.10)\end{array}$ & $\begin{array}{c}-0.0005 \\
(-1.42)\end{array}$ \\
\hline DIVDUM & $\begin{array}{c}-0.0091^{*} \\
(-1.68)\end{array}$ & $\begin{array}{c}0.0004 \\
(0.09)\end{array}$ & $\begin{array}{c}-0.0069 \\
(-1.53)\end{array}$ & $\begin{array}{c}-0.0166^{* * *} \\
(-2.31)\end{array}$ & $\begin{array}{c}-0.0034 \\
(-0.61)\end{array}$ \\
\hline$D A Y S$ & $\begin{array}{c}0.0002 \\
(1.32)\end{array}$ & $\begin{array}{c}-0.0031 \\
(-1.55)\end{array}$ & $\begin{array}{l}0.0001 \\
(1.07)\end{array}$ & $\begin{array}{c}-0.0001 \\
(-0.42)\end{array}$ & $\begin{array}{l}0.0026 \\
(1.02)\end{array}$ \\
\hline$L O S S$ & $\begin{array}{c}0.0037 \\
(0.78)\end{array}$ & $\begin{array}{l}0.0001 \\
(0.01)\end{array}$ & $\begin{array}{c}0.0029 \\
(0.71)\end{array}$ & $\begin{array}{c}-0.0126^{* *} \\
(-2.02)\end{array}$ & $\begin{array}{c}0.0040 \\
(0.76)\end{array}$ \\
\hline RIGHTDUM & $\begin{array}{c}-0.0036 \\
(-0.85)\end{array}$ & $\begin{array}{c}0.0004 \\
(0.06)\end{array}$ & $\begin{array}{c}-0.0027 \\
(-0.79)\end{array}$ & & \\
\hline PUBLICDUM & $\begin{array}{c}0.0152^{*} \\
(1.89)\end{array}$ & & $\begin{array}{c}0.0156^{*} \\
(1.95)\end{array}$ & & \\
\hline Intercept & $\begin{array}{c}0.0131 \\
(0.70)\end{array}$ & $\begin{array}{c}0.0303 \\
(1.06)\end{array}$ & $\begin{array}{c}0.0114 \\
(1.06)\end{array}$ & $\begin{array}{r}0.0249 \\
(1.03)\end{array}$ & $\begin{array}{c}0.0304^{* *} \\
(2.11)\end{array}$ \\
\hline Industry \& Year FE & Included & Included & Included & Included & Included \\
\hline $\mathrm{N}$ & 922 & 127 & 1049 & 162 & 809 \\
\hline Adjusted- $\mathrm{R}^{2}$ & $6.05 \%$ & $12.69 \%$ & $6.52 \%$ & $3.70 \%$ & $4.24 \%$ \\
\hline
\end{tabular}

This table presents results on the change in the market reaction to issuing SEOs following IFRS adoption among low-divergence and high-divergence firms between 2001 and 2008 using a difference-in-differences research design. The first two columns report results from the OLS regressions of cumulative abnormal returns on a set of firm characteristics and the IFRS dummy, using the low-divergence and the high-divergence samples respectively, between 2001 and 2008. The third column reports the results from the OLS regression of cumulative abnormal returns on a set of firm characteristics and the difference-in-differences dummies using the full sample between 2001 and 2008. The fourth and the fifth columns report the results from the OLS regression of cumulative abnormal returns for Rights and Placements offerings on a set of firm characteristics and the differencein-differences dummies using the full sample between 2001 and 2008. All variables are defined in Appendix A. All continuous variables are winsorized at the $1 \%$ level to mitigate the influence of outliers. All regressions include year and industry fixed effects. The t-statistics, presented in parentheses below the coefficients, are calculated using White (1980) standard errors. ${ }^{*}{ }^{* * *},{ }^{* * *}$ Denote significance at the $10 \%, 5 \%$, and $1 \%$ levels, respectively. 
Table 5. The change in the propensity to issue SEOs following IFRS adoption (H3)

\begin{tabular}{|c|c|c|c|c|c|c|}
\hline & \multicolumn{3}{|c|}{ Time period: 2001 - 2008} & \multicolumn{3}{|c|}{ Time period: 2003 - 2006} \\
\hline & Low-divergence & High-divergence & All & Low-divergence & High-divergence & All \\
\hline & SEODUM & SEODUM & SEODUM & SEODUM & SEODUM & SEODUM \\
\hline POST & $\begin{array}{c}0.0419^{* * * *} \\
(2.65)\end{array}$ & $\begin{array}{c}0.0905^{* * * *} \\
(2.96)\end{array}$ & $\begin{array}{c}0.0420^{* * * *} \\
(2.74)\end{array}$ & $\begin{array}{c}-0.0072 \\
(-0.40)\end{array}$ & $\begin{array}{c}0.1067^{* * *} \\
(3.23)\end{array}$ & $\begin{array}{c}-0.0063 \\
(-0.36)\end{array}$ \\
\hline HIGHDIV & & & $\begin{array}{c}-0.0453 \\
(-1.45)\end{array}$ & & & $\begin{array}{c}-0.0967^{* * * *} \\
(-3.27)\end{array}$ \\
\hline POST * HIGHDIV & & & $\begin{array}{c}0.0658 \\
(1.57)\end{array}$ & & & $\begin{array}{c}0.1549^{* * * *} \\
(2.70)\end{array}$ \\
\hline LOGTA & $\begin{array}{c}0.0027 \\
(0.56)\end{array}$ & $\begin{array}{c}0.0150^{* *} \\
(2.22)\end{array}$ & $\begin{array}{c}0.0064 \\
(1.63)\end{array}$ & $\begin{array}{c}0.0140^{* *} \\
(2.53)\end{array}$ & $\begin{array}{c}0.0275^{* * *} \\
(3.39)\end{array}$ & $\begin{array}{c}0.0179^{* * * *} \\
(4.00)\end{array}$ \\
\hline$L E V$ & $\begin{array}{c}-0.0830^{* * *} \\
(-3.67)\end{array}$ & $\begin{array}{c}-0.0903 \\
(-1.20)\end{array}$ & $\begin{array}{c}-0.0789^{* * *} \\
(-3.82)\end{array}$ & $\begin{array}{c}-0.0976^{* * *} \\
(-3.33)\end{array}$ & $\begin{array}{c}0.0258 \\
(0.37)\end{array}$ & $\begin{array}{c}-0.0725^{* * *} \\
(-2.85)\end{array}$ \\
\hline$R O A$ & $\begin{array}{c}-0.0488^{* *} \\
(-2.48)\end{array}$ & $\begin{array}{c}-0.0797 \\
(-1.08)\end{array}$ & $\begin{array}{c}-0.0506^{* * *} \\
(-2.76)\end{array}$ & $\begin{array}{c}0.0009 \\
(0.03)\end{array}$ & $\begin{array}{c}0.0059 \\
(0.05)\end{array}$ & $\begin{array}{c}0.0023 \\
(0.08)\end{array}$ \\
\hline TOBINQ & $\begin{array}{c}-0.0031 \\
(-0.83)\end{array}$ & $\begin{array}{c}0.0065 \\
(0.86)\end{array}$ & $\begin{array}{c}-0.0020 \\
(-0.60)\end{array}$ & $\begin{array}{l}0.0015 \\
(0.28)\end{array}$ & $\begin{array}{c}-0.0203 \\
(-0.58)\end{array}$ & $\begin{array}{l}0.0016 \\
(0.32)\end{array}$ \\
\hline$T A N G$ & $\begin{array}{c}0.0050 \\
(0.14)\end{array}$ & $\begin{array}{c}0.0987 \\
(1.20)\end{array}$ & $\begin{array}{c}0.0119 \\
(0.37)\end{array}$ & $\begin{array}{c}0.0008 \\
(0.02)\end{array}$ & $\begin{array}{c}0.0352 \\
(0.48)\end{array}$ & $\begin{array}{c}0.0035 \\
(0.10)\end{array}$ \\
\hline$L I Q D T$ & $\begin{array}{c}-0.0958^{* * *} \\
(-2.24)\end{array}$ & $\begin{array}{c}-0.0086 \\
(-0.06)\end{array}$ & $\begin{array}{c}-0.0759^{*} \\
(-1.90)\end{array}$ & $\begin{array}{c}-0.0466 \\
(-0.93)\end{array}$ & $\begin{array}{c}-0.1159 \\
(-0.71)\end{array}$ & $\begin{array}{c}-0.0314 \\
(-0.67)\end{array}$ \\
\hline$R N D$ & $\begin{array}{c}0.0769 \\
(1.03)\end{array}$ & $\begin{array}{c}-0.4381^{*} \\
(-1.92)\end{array}$ & $\begin{array}{c}0.0144 \\
(0.21)\end{array}$ & $\begin{array}{c}0.1710^{* *} \\
(2.21)\end{array}$ & $\begin{array}{c}-0.0416 \\
(-0.22)\end{array}$ & $\begin{array}{c}0.1326^{*} \\
(1.90)\end{array}$ \\
\hline DIVDUM & $\begin{array}{c}-0.0323 \\
(-1.38)\end{array}$ & $\begin{array}{c}-0.0733^{*} \\
(-1.80)\end{array}$ & $\begin{array}{c}-0.0411^{* *} \\
(-2.03)\end{array}$ & $\begin{array}{c}-0.0050 \\
(-0.19)\end{array}$ & $\begin{array}{c}-0.0380 \\
(-0.97)\end{array}$ & $\begin{array}{c}-0.0126 \\
(-0.53)\end{array}$ \\
\hline LOSS & $\begin{array}{c}0.0487^{* *} \\
(2.33)\end{array}$ & $\begin{array}{c}0.0530 \\
(1.34)\end{array}$ & $\begin{array}{c}0.0508^{* * * *} \\
(2.77)\end{array}$ & $\begin{array}{c}0.0362 \\
(1.47)\end{array}$ & $\begin{array}{c}0.0 .958^{*} \\
(1.79)\end{array}$ & $\begin{array}{c}0.0510^{\text {*** }} \\
(2.34)\end{array}$ \\
\hline RIGHTDUM & $\begin{array}{c}-0.0579^{* *} \\
(-2.24)\end{array}$ & $\begin{array}{c}-0.0014 \\
(-0.04)\end{array}$ & $\begin{array}{c}-0.0466^{* *} \\
(-2.27)\end{array}$ & $\begin{array}{c}0.0378 \\
(1.26)\end{array}$ & $\begin{array}{c}0.0155 \\
(0.37)\end{array}$ & $\begin{array}{c}0.0348 \\
(1.45)\end{array}$ \\
\hline PUBLICDUM & $\begin{array}{c}-0.0272 \\
(-1.06)\end{array}$ & & $\begin{array}{c}-0.0264 \\
(-1.07)\end{array}$ & $\begin{array}{c}0.0355 \\
(1.20)\end{array}$ & & $\begin{array}{c}0.0336 \\
(1.17)\end{array}$ \\
\hline Intercept & $\begin{array}{c}-0.8263^{* *} \\
(-2.07)\end{array}$ & $\begin{array}{c}-2.1648^{* * *} \\
(-2.51)\end{array}$ & $\begin{array}{c}-1.0560^{* * *} \\
(-3.02)\end{array}$ & $\begin{array}{c}-1.8955^{* * * *} \\
(-2.79)\end{array}$ & $\begin{array}{c}-5.3204^{* * *} \\
(-3.07)\end{array}$ & $\begin{array}{c}-2.3404^{\text {*** }} \\
(-3.98)\end{array}$ \\
\hline Industry \& Year FE & Included & Included & Included & Included & Included & Included \\
\hline $\mathrm{N}$ & 3101 & 673 & 3774 & 1567 & 328 & 1895 \\
\hline Pseudo- $\mathrm{R}^{2}$ & $4.52 \%$ & $6.70 \%$ & $4.96 \%$ & $5.23 \%$ & $17.74 \%$ & $5.02 \%$ \\
\hline Number of Issues & 765 & 125 & 890 & 253 & 48 & 301 \\
\hline
\end{tabular}

This table presents results on the change in the propensity to issue SEOs following IFRS adoption among low-divergence and high-divergence firms between 2001 and 2008 and between 2003 and 2006 using a difference-in-differences research design. The first two columns report the marginal effects of the logistic regressions of the SEO dummy on a set of firm characteristics and the IFRS dummy, using the low-divergence and the high-divergence samples respectively, between 2001 and 2008. The third column reports the marginal effects of the logistic regression of the SEO dummy on a set of firm characteristics and the difference-in-differences dummies, using the full sample between 2001 and 2008 . Column 4 and Column 5 report the marginal effects of the logistic regressions of the SEO dummy on a set of firm characteristics and the IFRS dummy, using the low-divergence and the high-divergence samples respectively, between 2003 and 2006. The last column reports the marginal effects of the logistic regression of the SEO dummy on a set of firm characteristics and the difference-in-differences dummies, using the full sample between 2003 and 2006 . All variables are defined in Appendix A. All continuous variables are winsorized at the $1 \%$ level to mitigate the influence of outliers. The z-statistics, presented in parentheses below the coefficients, are calculated using White (1980) standard errors. ${ }^{*},{ }^{* *},{ }^{* * *}$ Denote significance at the $10 \%, 5 \%$, and $1 \%$ levels, respectively. 
Table 6: Replicating the analysis using a matched sample and controlling for self-selection bias

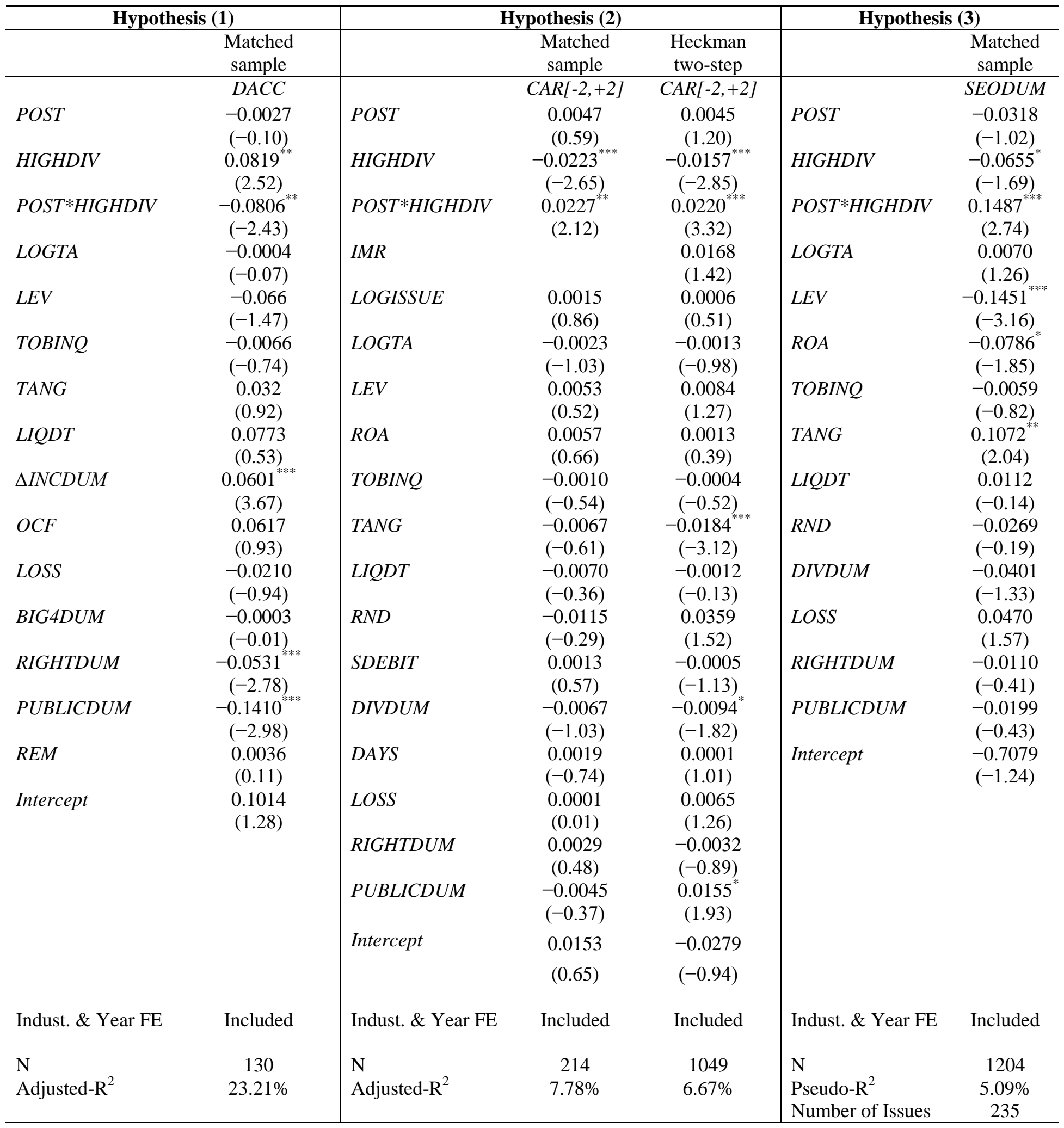

This table presents difference-in-differences results based on matched samples for all models (Hypotheses 1, 2, and 3) and Heckman two-step regression for the market reaction model (Hypothesis 2) between 2001 and 2008. The matching process uses the CEM technique based on Total Assets, Industry and IFRS. The Inverse Mills Ratio (IMR) in the Heckman two-step regression is calculated using $S A L E S$ as the exclusion restriction in the first step (Kim and Purnandum, 2014). All variables are defined in Appendix A. All continuous variables are winsorized at the 1\% level to mitigate the influence of outliers. The t-statistics, presented in parentheses below the coefficients, are calculated using White (1980) standard errors. ${ }^{*}, * * * * *$ Denote significance at the $10 \%, 5 \%$, and $1 \%$ levels, respectively. 